Subscriber access provided by - Access paid by the | UCSB Libraries

Article

\title{
Isotopic composition of inorganic mercury and methylmercury downstream of a historical gold mining region
}

Patrick Michael Donovan, Joel D. Blum, Michael B. Singer, Mark C. Marvin-DiPasquale, and Martin Tsz Ki Tsui Environ. Sci. Technol., Just Accepted Manuscript • DOI: 10.1021/acs.est.5b04413 • Publication Date (Web): 20 Jan 2016

Downloaded from http://pubs.acs.org on January 22, 2016

Just Accepted

"Just Accepted" manuscripts have been peer-reviewed and accepted for publication. They are posted online prior to technical editing, formatting for publication and author proofing. The American Chemical Society provides "Just Accepted" as a free service to the research community to expedite the dissemination of scientific material as soon as possible after acceptance. "Just Accepted" manuscripts appear in full in PDF format accompanied by an HTML abstract. "Just Accepted" manuscripts have been fully peer reviewed, but should not be considered the official version of record. They are accessible to all readers and citable by the Digital Object Identifier (DOI®). "Just Accepted" is an optional service offered to authors. Therefore, the "Just Accepted" Web site may not include all articles that will be published in the journal. After a manuscript is technically edited and formatted, it will be removed from the "Just Accepted" Web site and published as an ASAP article. Note that technical editing may introduce minor changes to the manuscript text and/or graphics which could affect content, and all legal disclaimers and ethical guidelines that apply to the journal pertain. ACS cannot be held responsible for errors or consequences arising from the use of information contained in these "Just Accepted" manuscripts. 


\section{Isotopic composition of inorganic mercury and}

\section{methylmercury downstream of a historical gold}

\section{mining region}

Patrick M. Donovan*1, Joel D. Blum¹, Michael B. Singer ${ }^{2,3}$, Mark Marvin-DiPasquale ${ }^{4}$,Martin T.K. Tsui ${ }^{5}$

1 University of Michigan, Department of Earth and Environmental Sciences, 1100 N. University Ave., Ann Arbor, MI, 48109, USA

2 University of St Andrews, Department of Earth and Environmental Sciences, North St., St Andrews, KY16 9AL UK

${ }^{3}$ Earth Research Institute, University of California Santa Barbara, Santa Barbara, CA, 93106 USA

${ }^{4}$ U.S. Geological Survey, Menlo Park, CA, 94025, USA

${ }^{5}$ Department of Biology, University of North Carolina at Greensboro, Greensboro, NC, 27402, USA

* Corresponding Author: pmdon@umich.edu, phone: 734.763.9368. 


\section{Keywords}

1 Mercury Isotopes, Yuba River, Feather River, Sediment, Benthic Macroinvertebrates

3 Abstract

$4 \quad$ We measured total mercury (THg) and monomethyl mercury (MMHg) concentrations and

5 mercury $(\mathrm{Hg})$ isotopic compositions in sediment and aquatic organisms from the Yuba River

6 (California, USA) to identify Hg sources and biogeochemical transformations downstream of a

7 historical gold mining region. Sediment THg concentrations and $\delta^{202} \mathrm{Hg}$ decreased from the upper

8 Yuba Fan to the lower Yuba Fan and the Feather River. These results are consistent with the release

9 of Hg during gold mining followed by downstream mixing and dilution. The Hg isotopic

10 composition of Yuba Fan sediment $\left(\delta^{202} \mathrm{Hg}=-0.38 \pm 0.17 \%\right.$ and $\Delta^{199} \mathrm{Hg}=0.04 \pm 0.03 \%$; mean \pm

11 1SD, n=7) provides a fingerprint of inorganic $\mathrm{Hg}(\mathrm{IHg})$ that could be methylated locally or after

12 transport downstream. The isotopic composition of MMHg in the Yuba River food web was

13 estimated using biota with a range of \%MMHg (the percent of THg present as MMHg) and

14 compared to IHg in sediment, algae and the food web. The estimated $\delta^{202} \mathrm{Hg}$ of MMHg prior to

15 photodegradation ( -1.29 to $-1.07 \%$ ) was lower than that of IHg and we suggest this is due to

16 mass-dependent fractionation (MDF) of up to $-0.9 \%$ o between IHg and MMHg. This result is in

17 contrast to net positive MDF ( +0.4 to $+0.8 \%$ ) previously observed in lakes, estuaries, coastal

18 oceans and forests. We hypothesize that this unique relationship could be due to differences in the

19 extent or pathway of biotic MMHg degradation in stream environments. 
21 TOC Art

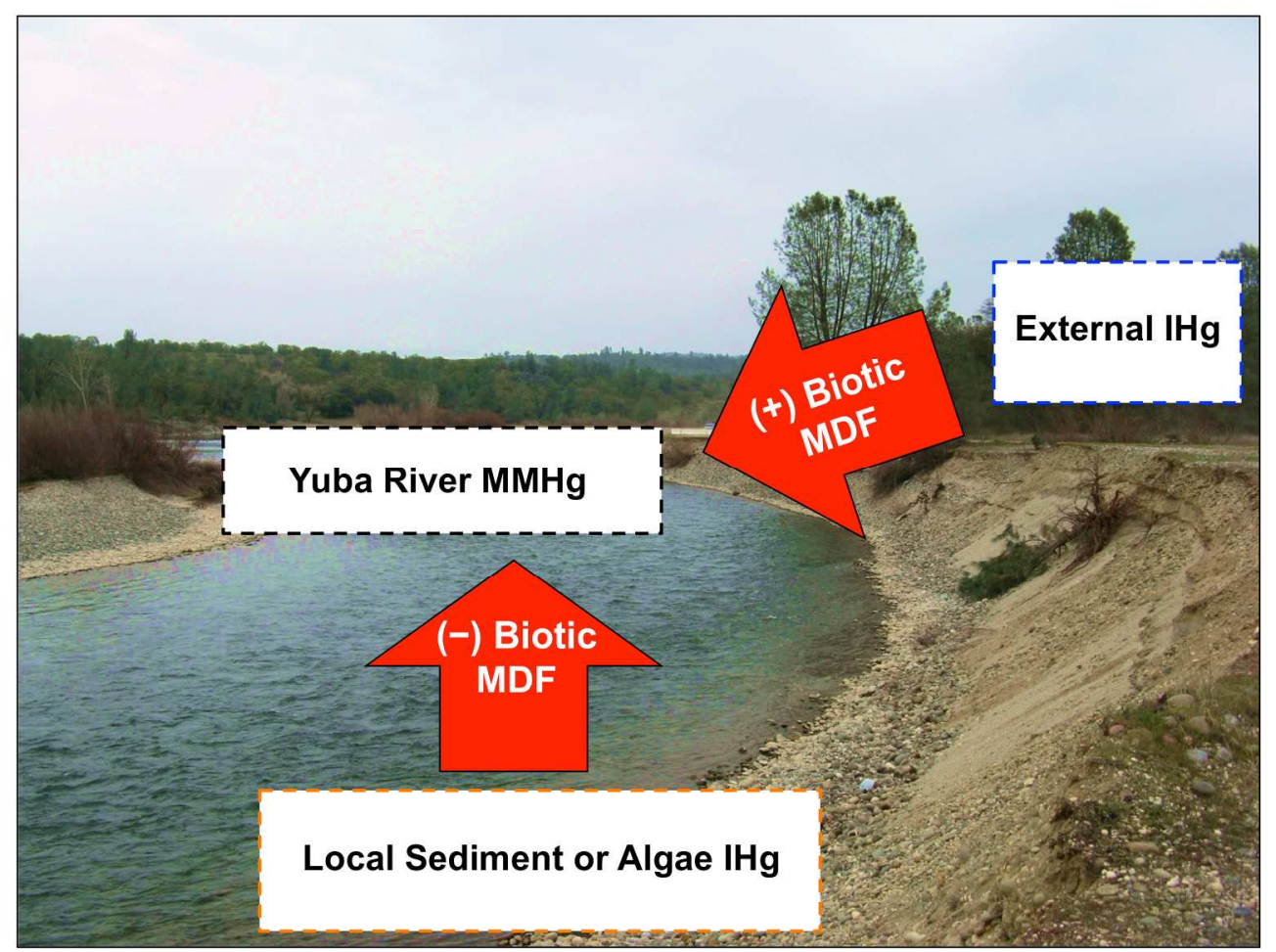

22 


\section{Introduction}

Mercury $(\mathrm{Hg})$ is a globally distributed neurotoxic pollutant that bioaccumulates in food webs as monomethyl mercury (MMHg). The amount of Hg actively cycling in the environment has increased due to anthropogenic activities such as mining, coal combustion, and industrial Hg use. ${ }^{1}$ In the $19^{\text {th }}$ century, metallic $\mathrm{Hg}$ was widely used to enhance gold $(\mathrm{Au})$ recovery during hydraulic mining of placer deposits throughout the Sierra Nevada Mountain Range in California. During hydraulic mining, large volumes of sediment were washed through sluices containing Hg to amalgamate fine particles of $\mathrm{Au}$ and up to $30 \%$ of the $\mathrm{Hg}$ used was released to the environment. ${ }^{2}$

31 The Hg-contaminated sediment was released downstream and deposited in river valleys along the western front of the Sierra Nevada, with significant amounts of sediment entering lowland channels and reaching San Francisco Bay (SF Bay). ${ }^{3}$ Sediment from Au mining persists in anthropogenic fan deposits evident in terraces and banks alongside rivers draining former mining districts. ${ }^{4}$ One of the largest of these is the Yuba Fan, a massive deposit of mining derived sediment $\left(252 \times 10^{6} \mathrm{~m}^{3}\right)$ which grades from the Sierra Nevada piedmont to the Central Valley.4, 5 This sediment has total Hg concentrations (THg) consistently two to three times higher than pre-mining sediment.4, 5 The lower Yuba River, between Englebright Dam and the Feather River, flows through this sediment deposit. Erosion of the Yuba Fan supplies inorganic Hg (IHg) laden sediment to local and downstream environments, particularly during major flood events. ${ }^{4}$

IHg in sediment can be transformed by methylating microbes (e.g., sulfate and iron reducing

42 bacteria) into bioaccumulative MMHg and this process is controlled by a variety of geochemical 43 parameters (e.g., nutrient and organic matter availability, redox conditions, $\mathrm{Hg}$ speciation, etc.). ${ }^{6}$ In

44 general, conditions that promote IHg methylation are often found in wetlands or estuarine

45 environments, ${ }^{7}$ such as in San Francisco Bay where MMHg production and bioaccumulation is well

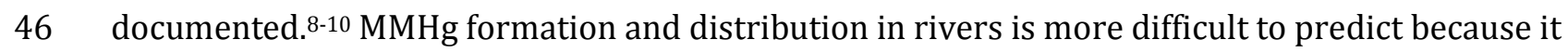


47

can be a function of both watershed landscape characteristics (i.e., wetland density, land use, etc.) ${ }^{11}$, 12 and in-stream processes (i.e., microbial community, hydrology, productivity). ${ }^{13-15}$ Thus, in watersheds with multiple potential IHg inputs, it is difficult to identify the origin of bioaccumulated MMHg using MMHg or THg concentrations alone. Nonetheless, MMHg biomagnifies in many riverine food webs ${ }^{11}$ and processes that govern $\mathrm{MMHg}$ formation and degradation in streams are of great interest. 14

In the Yuba River upstream of Englebright Dam (built in 1941 to trap hydraulic mining sediment), the spatial distribution, speciation and reactivity of $\mathrm{Hg}$ in sediment was previously documented, ${ }^{16,17}$ as were fish THg concentrations, ${ }^{18}$ and invertebrate THg and MMHg concentrations. ${ }^{16}$ Downstream of Englebright Dam, where the Yuba River flows through the Yuba Fan, previous work has shown high THg in bar, bank, terrace, and floodplain sediment. ${ }^{4} \mathrm{THg}$ concentrations were also measured in sediment deposited behind Daguerre Point Dam (built in 1910), a 7.3 m high overflow spillway dam located midway between Englebright Dam and the Feather River. ${ }^{5}$ However, no prior studies have investigated MMHg bioaccumulation in the lower Yuba River and the importance of high THg Yuba Fan sediment to MMHg bioaccumulation in resident biota was unknown. We hypothesized that sediment IHg could be methylated in situ, resulting in MMHg bioaccumulation in the local food web. We also considered whether MMHg might be derived from watershed sources upstream of the Yuba Fan and Englebright Dam. To better understand the processes by which MMHg enters riverine food webs we measured Hg stable isotope ratios in lower Yuba River sediment and biota.

Mercury has seven stable isotopes that undergo mass-dependent fractionation (MDF) and mass-independent fractionation (MIF) in the environment. Hg stable isotope ratios have become a useful tool for identifying anthropogenic Hg sources and tracing their transport and deposition in stream systems. ${ }^{19-23}$ Comparisons of Hg isotopes in sediment (mostly IHg) with fish or other biota 
71 (containing MMHg) have been used to infer transformations between IHg and MMHg (e.g.,

72 microbial IHg methylation, microbial MMHg degradation, and photochemical MMHg

73 degradation). ${ }^{24,25}$ More recent studies have estimated the isotopic composition of IHg and MMHg in

74 food webs by measuring Hg isotopes in biota with a range of \%MMHg values (percent of THg

75 present as MMHg). ${ }^{26-28}$ This approach tests whether mixing of isotopically distinct IHg and MMHg

76 pools can explain the Hg isotopic composition of all biota at a particular location, assuming these

77 pools do not vary widely during the study time period. Using this method, Kwon et al. $\left({ }^{27}\right)$ measured

$78 \mathrm{Hg}$ isotope ratios in estuarine sediment and biota along the U.S. northeast coast. From the estimated

79 isotopic composition of $\mathrm{MMHg}$, the authors were able to determine that organisms were primarily

80 exposed to MMHg from local sediment. In another study, MMHg isotopic composition was

81 estimated in the South Fork Eel River (California) to evaluate Hg exchange across ecosystem

82 boundaries via organismal movement, 2928 and longitudinal changes in MMHg photochemical

83 degradation. ${ }^{30}$ So far, investigation of MMHg in stream ecosystems using Hg isotopes has been

84 limited to the Eel River, which is a relatively remote, bedrock-dominated, free flowing river where

$85 \mathrm{Hg}$ is derived mainly from atmospheric deposition and there are no local $\mathrm{Hg}$ point sources.

Here we present the first $\mathrm{Hg}$ isotope study to investigate $\mathrm{Hg}$ sources and biogeochemical

87 transformations in sediment and biota in a river contaminated by historical Au mining. We report

$88 \mathrm{THg}$ and MMHg concentrations and $\mathrm{Hg}$ isotopic compositions of sediment, filamentous algae and

89 aquatic organisms from the lower Yuba River (six sites) and the Feather River (one site; SI Figure

90 1). A diverse suite of organisms was analyzed, including five types of benthic macroinvertebrates:

91 stonefly larva (Perlidae), caddisfly larva (Hydropsychidae), mayfly larva (Heptageniidae and

92 Ephemerellidae), aquatic worm (Oligochaeta), Asian clam (Corbicula fluminea), and two fish species:

93 riffle sculpin (Cottus gulosus) and speckled dace (Rhinichthys osculus). We estimated the isotopic

94 composition of both IHg and MMHg in the food web to (1) determine the source of bioaccumulated 
95 MMHg and (2) identify important microbial and photochemical processes governing Hg cycling in 96 this river system.

Materials and Methods

Sample Collection and Processing

Twelve sediment samples were analyzed from subaerial riverbanks and terraces at eight locations in the Yuba and Feather Rivers (Figure 1). Nine sediment samples were collected between

1022006 and 2008 by Singer et al. ${ }^{4}$ and three additional samples were collected in March 2013. Prior to 103 analysis, all sediment was either air dried (n=9; from Singer et al. ${ }^{4}$ ) or freeze-dried ( $n=3$ from 104 March 2013) and dry-sieved to $<63 \mu \mathrm{m}$. Aquatic organisms were collected from five sites in the 105 Yuba River: Rose Bar (RB), Parks Bar (PB), Hammon Grove (HG), Dantoni (Da), and Simpson Bridge 106 (SB), and one site downstream in the Feather River (FR; SI Figure 1). All organisms were collected 107 using a kick net, dip net or directly off gravel cobbles during sampling campaigns in March 2013 (at 108 RB, Da and FR) and June 2014 (all sites). Individual organisms were removed with clean stainless 109 steel tweezers, identified, sorted into composite samples (five or more individuals per sample, 110 except for riffle sculpin) and immediately frozen on dry ice. When individual organisms were 111 plentiful (i.e., more than $\sim 50$ individuals) they were collected as multiple composite samples and 112 analyzed separately (e.g., four stonefly samples at PB). Biotic samples were freeze-dried and then 113 ground into a powder with either an agate mortar and pestle or an alumina ball mixer mill prior to 114 analysis. Additional sample collection details are available in the Supporting Information. 
The concentration of MMHg (dry wt.) in freeze-dried sediment and biota was measured at

118 the U.S. Geological Survey (USGS; Menlo Park, CA). Sediment was sub-sampled (20-30 mg) and

119 extracted for MMHg using 25\% KOH/methanol (25 g of $\mathrm{KOH}$ in $100 \mathrm{~mL}$ methanol) at $60^{\circ} \mathrm{C}$ for four

120 hours. ${ }^{17}$ Biota was sub-sampled (3-7 mg) and extracted for $\mathrm{MMHg}$ using $30 \% \mathrm{HNO}_{3}$ at $60^{\circ} \mathrm{C}(12-16$

$121 \mathrm{~h})$, as adapted from ( ${ }^{31}$ ). Sediment and biota extract sub-samples were diluted, pH was adjusted

122 with citrate buffer and they were analyzed for MMHg by aqueous phase ethylation (with sodium

123 tetraethylborate) on an automated MMHg analyzer (MERX, Brooks Rand). ${ }^{32}$ For sediment MMHg

124 (analyzed in a single batch), the relative percent deviation (RPD) of analytical duplicates was 8.4\%

125 ( $n=1$ pair), matrix spike recovery was $107 \pm 1 \%(n=2)$, and certified reference material (CRM) ERM-

126 CC580 (estuarine sediment) recovery was 95\% (n=1). For biota, the mean RPD of analytical

127 duplicates was $3.0 \%(n=12$ pairs), matrix spike recoveries were $105 \pm 1 \%$ (mean $\pm S E, n=26)$, and

128 recoveries from NRC Tort-3 (lobster hepatopancreas) were $86 \pm 2 \%$ (mean \pm SE, $n=7$ ) and from

129 NIST-2967 (marine mussel tissue) were $94 \pm 3 \%$ (mean \pm SE, $n=7$ ).

THg Concentration and $\mathrm{Hg}$ Isotope Analysis

Hg was separated for THg concentration and Hg stable isotope measurements by offline

133 combustion, as described in detail elsewhere (e.g., ${ }^{28,33}$ ). Briefly, up to $1 \mathrm{~g}$ of sample was placed into

134 the first furnace of a two-furnace combustion system. The temperature of the first furnace was

135 increased to $750^{\circ} \mathrm{C}$ over six hours with the second furnace held at $1000^{\circ} \mathrm{C}$. $\mathrm{Hg}$ was released and

136 carried in a flow of $\mathrm{Hg}$-free $\mathrm{O}_{2}$ through the second furnace and into a $24 \mathrm{~g}$ trapping solution of $1 \%$

$137 \mathrm{KMnO}_{4}$ in $10 \% \mathrm{H}_{2} \mathrm{SO}_{4}$. These solutions were partially reduced with $2 \%(\mathrm{w} / \mathrm{w})$ of a $30 \%$ solution of

$138 \mathrm{NH}_{2} \mathrm{OH} \bullet \mathrm{HCl}$ and an aliquot was measured for THg by CV-AAS (Nippon MA-2000) to calculate the

139 sample dry wt THg concentration (based on the mass of Hg in solution and the sample mass

140 combusted). Compared to independent analysis by hot concentrated acid digestion and CV-AFS at 
141 USGS-Menlo Park, offline combustion recovered $107 \pm 11 \%$ (1SD, n=6) of $\mathrm{Hg}$ from biotic samples 142 and $97 \pm 11 \%(1 S D, n=15)$ of $\mathrm{Hg}$ from sediment samples. The content of each trap was then divided 143 into 1-5 g aliquots, treated with $0.3 \mathrm{ml}$ of $20 \% \mathrm{SnCl}_{2}$ and $0.3 \mathrm{ml}$ of $50 \% \mathrm{H}_{2} \mathrm{SO}_{4}$ and $\mathrm{Hg}$ was purged 144 into a secondary $1 \% \mathrm{KMnO}_{4}$ trap to isolate $\mathrm{Hg}$ from combustion residues and concentrate $\mathrm{Hg}$ for 145 isotopic analysis. An aliquot of this secondary trap solution was analyzed by CV-AAS (Nippon MA$1462000)$ and recoveries averaged $98 \pm 3 \%(1 S D ; n=36)$ for biota and $99 \pm 2 \%(1 S D ; n=15)$ for

147 sediment. The Hg isotopic composition of the secondary trap solution was then measured by cold 148 vapor multi-collector inductively coupled plasma mass spectrometry (CV-MC-ICP-MS; Nu 149 Instruments). Solutions were partially reduced with $2 \%(\mathrm{w} / \mathrm{w})$ of a $30 \%$ solution of $\mathrm{NH}_{2} \mathrm{OH} \bullet \mathrm{HCl}$ 150 and diluted to between 0.9 and $5 \mathrm{ng} / \mathrm{g}$. All $\mathrm{Hg}$ was reduced to $\mathrm{Hg}(0)$ online by the addition of $2 \%$

$151(\mathrm{w} / \mathrm{w}) \mathrm{SnCl}_{2}$ and carried in a stream of Ar gas to the MC-ICP-MS inlet. Instrumental mass bias was 152 corrected by introduction of an internal Tl standard (NIST 997) as a dry aerosol to the gas stream 153 and by strict sample standard bracketing using NIST 3133 with a matching concentration $( \pm 10 \%)$ 154 and solution matrix. ${ }^{34}$

155 Mercury stable isotope compositions are reported in permil (\%o) using delta notation

$156\left(\delta^{\mathrm{xxx}} \mathrm{Hg}\right)$ relative to NIST SRM 3133 (Eq. 1), with MDF based on the ${ }^{202} \mathrm{Hg} /{ }^{198} \mathrm{Hg}$ ratio $\left(\delta^{202} \mathrm{Hg}\right) \cdot{ }^{34} \mathrm{MIF}$ 157 is the deviation from theoretically predicted MDF and is reported in permil (\%o) using capital delta $158\left(\Delta^{\mathrm{xxx}} \mathrm{Hg}\right)$ notation (Eq. 2). In this study, we use $\Delta^{199} \mathrm{Hg}$ and $\Delta^{201} \mathrm{Hg}$ to report MIF where $\beta=0.252$ for $159 \Delta^{199} \mathrm{Hg}$ and $\beta=0.752$ for $\Delta^{201} \mathrm{Hg}^{34} \mathrm{All} \delta^{\mathrm{xxx}} \mathrm{Hg}$ and $\Delta^{\mathrm{xxx}} \mathrm{Hg}$ values are available in SI Tables 1,2 , and 3.

160 Equation [1]: $\delta^{\mathrm{xxx}} \mathrm{Hg}(\% 0)=\left(\left[\left({ }^{\mathrm{xxx}} \mathrm{Hg} /{ }^{198} \mathrm{Hg}\right)_{\text {sample }} /\left({ }^{\mathrm{xxx}} \mathrm{Hg} /{ }^{198} \mathrm{Hg}\right)_{\text {NIST3133 }}\right]-1\right) * 1000$

161 Equation [2]: $\Delta^{\mathrm{xx}} \mathrm{Hg}=\delta^{\mathrm{xxx}} \mathrm{Hg}-\left(\delta^{202} \mathrm{Hg} * \beta\right)$ Procedural blanks and CRMs (NRC TORT-2: lobster hepatopancreas and NIST 1944: New 163 York/New Jersey waterway sediment) were processed for THg and Hg isotopic composition in an 164 identical manner to samples. Process blanks for sediment and biota averaged $95 \pm 15$ pg (1SD, n=8) 
165 and $104 \pm 30 \mathrm{pg}(1 \mathrm{SD}, \mathrm{n}=6)$, respectively and accounted for between $0.2 \%$ to $1.8 \%$ of $\mathrm{Hg}$ in the final

166 trap solutions. THg for CRMs was within 5\% of certified values (SI Table 3) and recoveries during

167 secondary purge and trap were $94 \pm 4 \%$ (1SD, $n=6$, min=87\%) for NIST 1944 and $96 \pm 7 \%$ (1SD,

$168 \mathrm{n}=11, \min =80 \%$ ) for NRC Tort-2. The Hg isotopic composition of both CRMs was consistent with

169 previously reported values (SI Table 3).21, 24, 27-29, 35-39 The long-term analytical uncertainty of $\mathrm{Hg}$

170 isotope ratio measurements was estimated from the standard deviation (2SD) of the mean $\mathrm{Hg}$

171 isotopic composition of the secondary UM-Almadén standard over multiple analytical sessions. We

172 also estimated external reproducibility from replicate measurements of CRMs. The uncertainty

173 associated with CRMs was greater than uncertainty associated with the UM- Almadén standard (SI

174 Table 3). Therefore, we use the 2SD of mean Hg isotope values of replicate CRM measurements to

175 approximate uncertainty for sample measurements in this study $\left( \pm 0.08 \%\right.$ or for $\delta^{202} \mathrm{Hg}$ and $\pm 0.05 \%$ o

176 for $\left.\Delta^{199} \mathrm{Hg}\right)$.

\section{Results \& Discussion}

\section{Sediment THg and Hg Isotopic Composition}

Yuba River and Feather River sediment THg concentrations ranged from 170 to 6,820 ng/g,

$181 \delta^{202} \mathrm{Hg}$ values ranged from -0.95 to $0.72 \%$ and $\Delta^{199} \mathrm{Hg}$ values were near zero (mean=0.04 \pm

$1820.03 \%$; $1 \mathrm{SD}, \mathrm{n}=12$; SI Table 1 ). Sediment THg and $\delta^{202} \mathrm{Hg}$ generally decreased from the upper Yuba

183 Fan ( 0 to $20 \mathrm{~km}$ downstream of Englebright Dam) to the lower Yuba Fan (20 to $36 \mathrm{~km}$

184 downstream of Englebright Dam) and into the Feather River ( $>36 \mathrm{~km}$ downstream of Englebright

185 Dam; Figure 1). Metallic $\operatorname{Hg}(0)$ was used during the hydraulic mining of placer deposits in the upper

186 fan adjacent to Rose Bar between 1850 and the early 1900’s. Upper fan sediment (n=4) had the

187 highest THg concentrations (up to 6,820 ng/g) and somewhat variable $\delta^{202} \mathrm{Hg}\left(\delta^{202} \mathrm{Hg}=-0.04 \pm\right.$

$1880.52 \%$; mean $\pm 1 \mathrm{SD}$ ) due to one of the four sediment samples having an anomalous $\delta^{202} \mathrm{Hg}$ of 
$+0.71 \%$. The remaining three upper fan sediment samples had $\delta^{202} \mathrm{Hg}$ between -0.50 and $-0.18 \%$,

190 similar to previously analyzed sediment from a single tailings pile at Rose Bar $(-0.50 \%$ and

$191-0.64 \%$ ) ${ }^{40}$ The $\delta^{202} \mathrm{Hg}$ value of metallic $\mathrm{Hg}(0)$ has been reported to vary globally from -1.06 to

$1920.00 \%$ o (mean $=-0.39 \pm 0.37 \% 0,1 \mathrm{SD}, \mathrm{n}=7),{ }^{41}$ and is often similar to the $\delta^{202} \mathrm{Hg}$ of the $\mathrm{Hg}$ ore from

193 which it is derived. ${ }^{42}$ Sierra Nevada Au mining operations obtained metallic Hg from the CA Coast

194 Range, $^{2}$ where Hg ore deposits exhibit a wide range in $\delta^{202} \mathrm{Hg}(-0.64 \pm 0.84 \%$; mean $\pm 1 \mathrm{SD}$,

195 n=91). ${ }^{43}$ Metallic $\mathrm{Hg}(0)$ has also been shown to undergo complex transformations (i.e., dissolution,

196 oxidation, volatilization and sorption) upon its release during Au mining.44 Thus, the single high

$197 \quad \delta^{202} \mathrm{Hg}$ sediment sample could reflect metallic $\mathrm{Hg}(0)$ from a specific Au mine or during a specific

198 mining period or could have been fractionated by loss of isotopically light Hg in the stream

199 environment. Downstream in the lower Yuba Fan, THg concentrations decrease and $\delta^{202} \mathrm{Hg}$ values

200 are less variable. Lower fan sediment had THg between 170 and $309 \mathrm{ng} / \mathrm{g}$ and a mean $\delta^{202} \mathrm{Hg}$ of

$201-0.44 \pm 0.16 \%$ (1SD, $n=4)$. The smaller isotopic variability in this stream section suggests that

202 various Hg sources are relatively well homogenized. Although we did not measure the speciation of

203 Hg in Yuba Fan sediment here, previous work in the Upper Yuba River ${ }^{16,17}$ and elsewhere (e.g., ${ }^{45}$ )

204 has suggested that a significant proportion of $\mathrm{Hg}$ in $\mathrm{Au}$ mining derived sediment is present as $\mathrm{Hg}(0)$.

205 Our results are consistent with the presence of a metallic $\mathrm{Hg}(0)$ source: the mean $\mathrm{Hg}$ isotopic

206 composition of all Yuba Fan sediment $\left(\delta^{202} \mathrm{Hg}=-0.38 \pm 0.17 \%\right.$ and $\Delta^{199} \mathrm{Hg}=0.04 \pm 0.03 \%$; $1 \mathrm{SD}$,

$207 \mathrm{n}=7$, excluding one sample treated as an outlier) is similar to the mean $\delta^{202} \mathrm{Hg}$ of metallic $\mathrm{Hg}$

208 globally $(-0.39 \%)^{41}$ and to the average $\delta^{202} \mathrm{Hg}$ of Hg-ore in the CA Coast Range $(-0.64 \% 0) .{ }^{43}$

Downstream of the Yuba River, Feather River sediment had THg (218-413 ng/g) and mean

$211 \delta^{202} \mathrm{Hg}$ values $(-0.66 \pm 0.26 \%$, $1 \mathrm{SD}, \mathrm{n}=4)$ similar to the Yuba Fan. Multiple studies have shown that

212 sediment Hg isotopic compositions can be used to trace downstream Hg transport and mixing in 
213 rivers. ${ }^{19-21,23,46}$ Pre-mining sediment (i.e., less than $60 \mathrm{ng} / \mathrm{g}$ ) in subtidal sediment cores from SF Bay

214 had an average $\delta^{202} \mathrm{Hg}$ of $-0.98 \pm 0.06 \%$ and $\Delta^{199} \mathrm{Hg}$ of $0.17 \pm 0.03 \%$ (1SD, $\left.\mathrm{n}=5\right) .{ }^{40}$ Pre-mining

215 sediment in SF Bay was likely derived from watersheds draining the Sierra Nevada, including the

216 Yuba and Feather Rivers. If we assume this pre-mining sediment isotopic composition is similar to

217 uncontaminated sediment in the Yuba-Feather watershed, then the downstream decrease in THg

218 and gradual shift toward lower $\delta^{202} \mathrm{Hg}$ suggests dilution of mining derived $\mathrm{Hg}$ with uncontaminated

219 sediment (SI Figure 3). This is consistent with the model of progressively diluted hydraulic mining

220 sediment being remobilized and redeposited within the fan and exported from it.4,47,48 We use the

$221 \mathrm{Hg}$ isotope signature of Yuba Fan sediment $\left(\delta^{202} \mathrm{Hg}=-0.38 \pm 0.17 \%\right.$ and $\Delta^{199} \mathrm{Hg}=0.04 \pm 0.03 \%$;

222 mean $\pm 1 S D, n=7$, excluding one sample treated as an outlier) as a fingerprint of the large volume of

223 IHg that could be methylated within the Yuba River or exported downstream.

\section{Yuba and Feather River Biota}

\section{Biota THg and MMHg Concentrations}

Biota THg and MMHg concentrations in the Yuba and Feather Rivers were similar to

228 previous studies downstream of Au mining regions in the Sierra Nevada (e.g., ${ }^{16,49,50}$ ). The

229 concentrations in this study also overlap with THg and MMHg reported for biota in streams without

230 any local Hg point sources (e.g, ${ }^{11,51}$ ). Algae THg ranged from 57 to $186 \mathrm{ng} / \mathrm{g}$, likely due to the

231 variable accumulation of high THg Yuba Fan sediment. However MMHg levels in filamentous algae

232 increased with distance downstream in the Yuba River, from $2.4 \mathrm{ng} / \mathrm{g}$ at Rose Bar to $17 \mathrm{ng} / \mathrm{g}$ at

233 Dantoni and $15 \mathrm{ng} / \mathrm{g}$ at Simpson Bridge. Algae MMHg levels were similar to the Eel River in the

234 northern California Coast Range (3 to $34 \mathrm{ng} / \mathrm{g}$ ), where the authors suggested that microbial

235 communities associated with algae might mediate in situ methylation of IHg. ${ }^{13,51}$ Benthic

236 macroinvertebrate MMHg concentrations ranged from 37 to $271 \mathrm{ng} / \mathrm{g}$ and there was no systematic 
237 change in MMHg or \%MMHg between sampling locations. These concentrations were more similar

238 to macroinvertebrates from streams affected by atmospheric deposition (e.g., Eel River ${ }^{51}$ and others

239 across the US ${ }^{11}$ ) than streams with significant Hg point sources (e.g., Cache Creek ${ }^{52}$ or streams near

240 Oak Ridge, TN53). The highest MMHg and THg concentrations in this study were measured in Asian

241 clam (79 to $271 \mathrm{ng} / \mathrm{g}$ and 168 to $426 \mathrm{ng} / \mathrm{g}$, respectively) and forage fish (380 to $406 \mathrm{ng} / \mathrm{g}$ and 377

242 to $436 \mathrm{ng} / \mathrm{g}$, respectively). Fish THg concentrations were within the reported range for these

243 species in US streams unaffected by Hg point sources. ${ }^{11}$ Consistent differences in \%MMHg were

244 observed among the organisms sampled, depending on their feeding behavior and presumed

245 trophic position. The $\%$ MMHg (mean \pm 1 SD) increased in the order: sediment $(1 \%, n=4)$,

246 filamentous algae $(6 \pm 6 \%, n=7)$, aquatic worm $(30 \pm 9 \%, n=4)$, Asian clam $(49 \pm 20 \%, n=3)$,

247 caddisfly larva $(66 \pm 7 \%, n=6)$, mayfly larva $(73 \pm 2 \%, n=3)$, stonefly larva $(80 \pm 9 \%, n=10)$,

248 speckled dace $(93 \%, \mathrm{n}=1)$ and riffle sculpin $(100 \%, \mathrm{n}=1)$. This trend is strongly indicative of the 249 preferential trophic transfer of MMHg via biomagnification in the Yuba River.

Biota Hg Isotopic Compositions

Aquatic organisms displayed a relatively narrow range in $\delta^{202} \mathrm{Hg}(-0.84$ to $-0.42 \%)$ but a wide range in $\Delta^{199} \mathrm{Hg}$ (0.06 to $1.17 \%$; SI Table 2). Following the approach of Tsui et al., ${ }^{28}$ we

254 performed linear regressions between \%MMHg and $\mathrm{Hg}$ isotope values to determine whether $\delta^{202} \mathrm{Hg}$

255 and $\Delta^{199} \mathrm{Hg}$ values in biota change with increasing \%MMHg (i.e., to test whether IHg and MMHg

256 pools are isotopically distinct). Sediment was excluded from these regressions to compare IHg in

257 the food web with IHg in sediment. In all biota (2013 and 2014) we observed a significant positive

258 relationship between $\Delta^{199} \mathrm{Hg}$ and $\% \mathrm{MMHg}\left(\mathrm{r}^{2}=0.78 ; \mathrm{p}<0.001\right)$, but a significant relationship was

259 not observed for $\delta^{202} \mathrm{Hg}\left(\mathrm{r}^{2}=0.01 ; \mathrm{p}=0.61\right)$. Because IHg and MMHg isotopic compositions could

260 vary across sampling seasons, benthic macroinvertebrates were grouped by collection year (2013 
261 and 2014) and the relationship between $\Delta^{199} \mathrm{Hg}$ and \%MMHg strengthened $\left(\mathrm{r}^{2}=0.96\right.$ for 2013 and

$262 \mathrm{r}^{2}=0.94$ for 2014). Positive relationships between $\Delta^{199} \mathrm{Hg}$ and $\% \mathrm{MMHg}$ have previously been

263 reported for biota in stream, lake and estuarine food webs. ${ }^{26-28}$ Although studies of lake, forest and

264 estuary food webs have also consistently found significant positive relationships between $\delta^{202} \mathrm{Hg}$

265 and \%MMHg, ${ }^{26-28}$ no such relationship was observed here (Yuba River) or in previous studies of the

266 Eel River. ${ }^{28}$ Overall, these results demonstrate the presence of isotopically distinct pools of IHg and

267 MMHg within the food web and are consistent with a model of binary mixing. Therefore, we use

268 these relationships to estimate the isotopic composition of the IHg and MMHg in the food web.

269 We estimated the isotopic composition of IHg and MMHg in the food web by extrapolation

270 to $100 \% \mathrm{IHg}$ and $100 \% \mathrm{MMHg}$ for $\Delta^{199} \mathrm{Hg}$ and $\delta^{202} \mathrm{Hg}$ (Figure 2a,b). Because there was no significant

271 relationship between $\delta^{202} \mathrm{Hg}$ and $\% \mathrm{MMHg}$, we also compared the estimated $\delta^{202} \mathrm{Hg}$ values for $\mathrm{MMHg}$

272 and IHg with the mean $\delta^{202} \mathrm{Hg}$ of organisms containing more than $70 \% \mathrm{MMHg}$ (i.e., predatory

273 macroinvertebrates, following Tsui et al. ${ }^{28}$ ) and less than 15\% MMHg (i.e., filamentous algae). The

274 mean $\delta^{202} \mathrm{Hg}$ of high \%MMHg biota $(-0.69 \pm 0.12 \%$ for $\mathrm{MMHg})$ and low $\% \mathrm{MMHg}$ biota $(-0.70 \pm$

$275 \quad 0.08 \%$ o for IHg) were not significantly different than linear regression estimates. Thus, these

276 methods result in similar $\delta^{202} \mathrm{Hg}$ values for MMHg and $\mathrm{IHg}$ and for consistency (with $\Delta^{199} \mathrm{Hg}$ ) we use

$277 \delta^{202} \mathrm{Hg}$ values that were estimated by linear regression. We estimate that in $2013 \mathrm{MMHg}$ had $\delta^{202} \mathrm{Hg}$

278 of $-0.72 \pm 0.05 \%$ and $\Delta^{199} \mathrm{Hg}$ of $0.90 \pm 0.04 \%$ and $\mathrm{IHg}$ had $\delta^{202} \mathrm{Hg}$ of $-0.63 \pm 0.06 \%$ and $\Delta^{199} \mathrm{Hg}$ of

$2790.05 \pm 0.04 \%$. We estimate that in $2014 \mathrm{MMHg}$ had $\delta^{202} \mathrm{Hg}$ of $-0.72 \pm 0.04 \%$ and $\Delta^{199} \mathrm{Hg}$ of $1.44 \pm$

$280 \quad 0.04 \%$ while IHg had $\delta^{202} \mathrm{Hg}$ of $-0.70 \pm 0.05 \%$ and $\Delta^{199} \mathrm{Hg}$ of $-0.04 \pm 0.05 \%$. The error reported

281 for these estimates is the $\pm 1 \mathrm{SE}$ of the intercept of the linear regression (i.e., at $100 \% \mathrm{IHg}$ or $\mathrm{MMHg}$ ).

282 These estimates for the isotopic compositions of MMHg and IHg are employed throughout the

283 following discussion. 
The estimated isotopic composition of bioaccumulated MMHg in the Yuba River reflects the isotopic composition of $\mathrm{Hg}$ source(s) and any fractionation that occurs during biogeochemical processes prior to entering the food web. ${ }^{54} \mathrm{The} \Delta^{199} \mathrm{Hg}: \Delta^{201} \mathrm{Hg}$ ratio in environmental samples such as fish and other biota is often compared to experimental ratios (e.g., ${ }^{55-57}$ ) to differentiate between photochemical MMHg degradation (slope of $~ 1.3$ ) and photochemical $\mathrm{Hg}(\mathrm{II})$ reduction (slope of 1.0). ${ }^{56}$ Biota from the Yuba and Feather Rivers had a $\Delta^{199} \mathrm{Hg}: \Delta^{201} \mathrm{Hg}$ ratio of $1.27 \pm 0.05$ (1SE, $\mathrm{n}=35$;

292 SI Figure 4), which is comparable to freshwater fish from lakes $(1.28 \pm 0.01 ; 1 S E, n=135)^{58}$ and consistent with other freshwater food web studies. ${ }^{26-29}$ This implies that the $\Delta^{199} \mathrm{Hg}$ and $\Delta^{201} \mathrm{Hg}$ values in biota result from MIF during photochemical MMHg degradation. ${ }^{56}$ Significant MMHg photodegradation likely occurs in the highly exposed, nearly treeless Yuba-Feather riparian zone and the residual MMHg (with positive $\Delta^{199} \mathrm{Hg}$ and $\Delta^{201} \mathrm{Hg}$ ) could then be incorporated into the food web. It is believed that the magnitude of MIF is directly proportional to the extent of photochemical MMHg degradation. ${ }^{56}$ Experimental studies have found the observed MIF is sensitive to DOC concentrations, ${ }^{56,57} \mathrm{MMHg}: \mathrm{DOC}$ ratios, ${ }^{59}$ and the wavelength of incident radiation. ${ }^{55}$ However, we should note that all experiments to date have used Hg concentrations (and thus Hg:DOC ratios) that

301 are higher than typically found in the environment. During a recent 4-year period (1999-2003), 302 dissolved organic carbon (DOC) concentrations in lower Yuba River surface water averaged $1.16 \pm$ $0.05 \mathrm{mg} / \mathrm{L}$ (1SE, $\mathrm{n}=104) .{ }^{60}$ Therefore, we use the experimental isotope fractionation data for 1 $304 \mathrm{mg} / \mathrm{L} \mathrm{DOC}$, and the estimated ${ }^{199} \mathrm{Hg}$ of MMHg, to calculate that $24 \%$ of the MMHg in the river had 305 undergone photodegradation in 2013 prior to incorporation into the food web, while $35 \%$ was 306 photodegraded in 2014. 
this study we observed significant differences in the extent of MMHg photodegradation between March 2013 (24\%) and June 2014 (35\%), but not between sampling locations within each time period. Such differences could have resulted from different environmental conditions (e.g.,

312 streamflow, water depth, or shading) or the timing of sampling (e.g., early spring vs. early summer),

313 but we are unable to identify the relative importance of these factors. However, we did observe that

314 fish sampled in 2014 (93-100\% MMHg) had $\Delta^{199} \mathrm{Hg}$ values of 0.79 and $0.84 \%$, which are nearly

315 identical to the estimated $\Delta^{199} \mathrm{Hg}$ of MMHg in $2013(0.90 \%)$. We suspect this similarity results

316 because the fish sampled are relatively long lived (1-3 years) and integrate the MMHg across

317 multiple years, in contrast to the seasonal growth and MMHg bioaccumulation of benthic

318 macroinvertebrates.

To isolate photochemical and non-photochemical processes in aquatic environments

320 Gehrke et al. $\left({ }^{25}\right)$ used experimental relationships to subtract the known MDF and MIF that occurs

321 during photochemical MMHg degradation. Subsequently, this approach has been used to infer MDF

322 from non-photochemical processes in many different field studies (e.g., in lakes, forests, and the

323 ocean). ${ }^{24,26-28,61,62}$ These studies have consistently found a positive $\delta^{202} \mathrm{Hg}$ offset between MMHg

324 prior to photodegradation ("pre-photodegraded MMHg") and IHg ( $\delta^{202} \mathrm{Hg}_{\text {pre-photodegraded MMHg }}$

$325 \delta^{202} \mathrm{Hg}_{\mathrm{IHg}}$ ) which has been interpreted to result from biotic MDF (e.g., the net result of biotic

326 methylation and biotic degradation) in the environment. ${ }^{24,25,27}$ For a similar comparison in the

327 Yuba River, we begin with the estimated MMHg isotopic composition and use experimentally

328 derived $\Delta^{199} \mathrm{Hg} / \delta^{202} \mathrm{Hg}$ slopes (2.43 for $\left.1 \mathrm{mg} / \mathrm{L} \mathrm{DOC}\right)^{56}$ to obtain an estimated $\delta^{202} \mathrm{Hg}$ value for pre-

329 photodegraded MMHg. Assuming that pre-photodegraded MMHg has $\Delta^{199} \mathrm{Hg}$ values near zero,

330 consistent with methylation of IHg in sediment, algae or the food web, the $\delta^{202} \mathrm{Hg}$ of pre-

331 photodegraded MMHg is estimated as $-1.07 \%$ in 2013 and $-1.29 \%$ in 2014 . These values are

332 much lower than the $\delta^{202} \mathrm{Hg}$ of IHg estimated in the food web $(-0.63 \pm 0.06 \%$ in 2013 and -

$3330.70 \pm 0.05 \%$ in 2014$)$ or measured in sediment $(-0.38 \pm 0.17 \%$ ) or algae $(-0.70 \pm 0.08 \%)$. Thus, 
334 there is a negative offset in $\delta^{202} \mathrm{Hg}$ between IHg and estimated pre-photodegraded MMHg in this 335 system (Figure 3). A negative $\delta^{202} \mathrm{Hg}$ offset has not been previously observed and we examine 336 possible explanations for this unique relationship below.

\section{Hg Sources in the Yuba River}

The Yuba River contains large quantities of IHg in streambed, bank and terrace sediment providing a persistent source of IHg to the river. The isotopic composition of two IHg pools were

341 characterized in this study: Yuba Fan sediment ( $>95 \% \mathrm{IHg}$ ) has a mean $\delta^{202} \mathrm{Hg}$ of $-0.38 \pm 0.17 \%$ o 342 and $\Delta^{199} \mathrm{Hg}$ of $0.04 \pm 0.03 \%$ (1SD, n=7; excluding one sample treated as an outlier) and filamentous algae $(85-98 \% \mathrm{IHg})$ has a mean $\delta^{202} \mathrm{Hg}$ of $-0.70 \pm 0.08 \%$ and $\Delta^{199} \mathrm{Hg}$ of $0.11 \pm 0.04 \%$ (1SD, $\mathrm{n}=7$ ).

344 As described above, we estimated the isotopic composition of IHg in the food web $\left(\delta^{202} \mathrm{Hg}=-0.70 \pm\right.$

$345 \quad 0.04 \%$ and $\Delta^{199} \mathrm{Hg}=0.05 \pm 0.07 \%$ ) and these $\delta^{202} \mathrm{Hg}$ values are similar to algae and slightly lower

346 than Yuba Fan sediment (Figure 3). Therefore, we suggest that IHg in the food web is directly

347 accumulated from sediment and algae, likely because these materials provide a direct dietary

348 resource for benthic macroinvertebrates.

We have estimated the isotopic composition of MMHg (by linear regression) and prephotodegraded MMHg (MMHg minus the MIF and MDF from MMHg photodegradation) in the Yuba

351 River. MMHg could be produced in situ by methylation of sediment IHg in the hyporheic zone or

352 associated with benthic biofilms and filamentous algae.13, 63-65 If so, then either a bioavailable pool of $353 \mathrm{IHg}$ with a $\delta^{202} \mathrm{Hg}$ lower than bulk sediment is preferentially methylated or net negative MDF (of up 354 to $-0.9 \%$ ) occurs between IHg and pre-photodegraded MMHg (Figure 4a). Alternatively, the 355 presence and bioaccumulation of MMHg in some streams can be a function of watershed 356 characteristics that promote Hg deposition and methylation. ${ }^{11,12,14,66}$ If MMHg in the lower Yuba 
River were derived from external or upstream sources, and not produced in situ, then Yuba Fan sediment might only be a source of IHg (not MMHg) to the food web.

We explore potential external Hg sources by comparing known isotopic compositions of these sources with the estimated isotopic composition of Yuba River MMHg and pre-photodegraded MMHg. In lakes and oceans, atmospheric deposition may provide a readily reactive IHg source that can be methylated leading to MMHg in the food web. ${ }^{67} 61$ In a previous study, precipitation collected near coastal CA and SF Bay had a Hg isotopic composition $\left(\delta^{202} \mathrm{Hg}=0.06 \pm 0.03 \%\right.$ and $\Delta^{199} \mathrm{Hg}=$ $0.30 \pm 0.05 \%$; mean $\pm 1 \mathrm{SD}, \mathrm{n}=3)^{40}$ consistent with studies of precipitation unaffected by local $\mathrm{Hg}$ point sources (i.e., $\delta^{202} \mathrm{Hg}$ near zero and significant positive $\Delta^{199} \mathrm{Hg}$ ). ${ }^{33,68-70}$ Significant positive $\Delta{ }^{199} \mathrm{Hg}$ in regional precipitation $\left(\Delta^{199} \mathrm{Hg}=0.30 \pm 0.05 \%\right.$ ), but a lack of significant positive $\Delta^{199} \mathrm{Hg}$ estimated for IHg in the food web $\left(\Delta^{199} \mathrm{Hg}\right.$ of $\left.0.05 \pm 0.07 \% 0\right)$, suggests that biota in the Yuba River do not obtain IHg from precipitation. If IHg in precipitation was the precursor to MMHg in Yuba River biota, then significant MDF of approximately -1 \%o would be required to link precipitation IHg to pre-photodegraded MMHg. Furthermore, this IHg source would have to be preferentially methylated despite the presence of large volumes of IHg in Yuba Fan sediment.

It is also possible that IHg accumulated in the watershed (i.e., upstream of Englebright Dam)

373 could be a source of MMHg to the lower Yuba River. Forest soils accumulate Hg from dry

374 deposition, leaf litter, and precipitation. ${ }^{33,71}$ This IHg could be methylated in wetlands, floodplains

375 or reservoirs and transported to aquatic environments during runoff events. ${ }^{72-74}$ Basal resources

376 (foliage, soil, and submerged leaf litter) from the Eel River in northern California had relatively low

$377 \delta^{202} \mathrm{Hg}\left(-2.53\right.$ to $-1.54 \%$ ) and negative $\Delta^{199} \mathrm{Hg}(-0.37$ to $-0.15 \% 0) .{ }^{28}$ Similar $\mathrm{Hg}$ isotopic

378 compositions have been found in forest floor samples from the upper Midwest $\left(\delta^{202} \mathrm{Hg}=-1.05\right.$ to

$379-1.88 \%$ and $\Delta^{199} \mathrm{Hg}=-0.15$ to $\left.-0.25 \% 0\right)^{33}$ and in low $\mathrm{THg}$ sediment from Tennessee streams

$380\left(\delta^{202} \mathrm{Hg}=-1.40 \pm 0.06 \%\right.$ and $\Delta^{199} \mathrm{Hg}=-0.26 \pm 0.03 \%$, mean $\left.\pm 1 \mathrm{SD}, \mathrm{n}=6\right) .{ }^{21}$ Without Au mining 
381 impacts, we would expect the isotopic composition of geogenic and atmospheric Hg sources

382 accumulated in the Yuba River watershed to have a similar range in isotopic composition (i.e.,

$383 \delta^{202} \mathrm{Hg}$ between -1 and $-2.5 \%$ and slight negative $\Delta^{199} \mathrm{Hg}$ ). Because the estimated $\delta^{202} \mathrm{Hg}$ of pre-

384 photodegraded MMHg in the Yuba River overlaps with these IHg pools (Figure 4b), we cannot rule

385 out upstream or terrestrial IHg as a possible source of MMHg in the Yuba River. However, THg in

386 Yuba Fan sediment is at least three times, and up to 100 times, higher than background sediment

387 and is found in locations where methylation is thought to occur (e.g., streambed, floodplains,

388 hyporheic zone, and associated with filamentous algae).12, 13, 65, 75, 76 The Hg isotope data suggest that

389 IHg in the food web is directly accumulated from sediment and algae (Figure 3) and it follows that

390 MMHg is also accumulated from dietary resources. From Hg isotope data alone, we cannot rule out

391 the possibility that external sources of MMHg (e.g., upstream reservoirs, precipitation) become

392 associated with lower Yuba River sediment or algae (which could then be accumulated in the Yuba

393 River food web). Nonetheless, below we consider the scenario where IHg in co-located sediment

394 and algae is methylated in situ and then bioaccumulated as MMHg in the lower Yuba River.

396 In Stream Processes and MDF

It is likely that only a fraction of the IHg in sediment is in a chemical form that is available

399 for microbial methylation. ${ }^{12,17,77-79}$ If this fraction has lower $\delta^{202} \mathrm{Hg}$ values than bulk sediment, then

400 the negative $\delta^{202} \mathrm{Hg}$ offset between sediment IHg and pre-photodegraded MMHg may be an artifact

401 of the difference between bulk sediment $\delta^{202} \mathrm{Hg}$ and the $\delta^{202} \mathrm{Hg}$ of labile IHg. If we assume biotic

402 MDF occurs in a consistent manner to that observed in previous studies (i.e., MDF of $+0.4 \%$ to

$403+0.8 \% 0), 24,25,27,62$ then from the estimated pre-photodegraded MMHg $\delta^{202} \mathrm{Hg}$ value $(-1.29$ to

$404-1.07 \%$ ) we would predict that the labile $\mathrm{IHg}$ fraction would have $\delta^{202} \mathrm{Hg}$ between -1.5 and 
405

406

407

408

409

410

411

412

413

414

415

416

417

418

420

421

422

423

424

425

426

427

428

$-2.1 \%$. Multiple experiments have shown that leachates (water soluble, thiosulfate soluble and weak acid soluble) have consistently higher $\delta^{202} \mathrm{Hg}$ (up to $1.3 \%$ ) than bulk sediment and mine wastes. ${ }^{80-82} \mathrm{HgS}$ species and Hg sorbed to colloids, both of which could be present in Yuba Fan Au mine tailings, ${ }^{17}$ are susceptible to methylation in the hyporheic zone or inundated floodplains. 45 Studies have demonstrated that precipitation of $\mathrm{HgS}, \beta-\mathrm{HgS}$ and $\mathrm{HgO}$ from solution, ${ }^{19,}{ }^{83}$ sorption of $\mathrm{Hg}$ to goethite, ${ }^{84}$ and binding of $\mathrm{Hg}$ to thiol groups in natural organic matter, 85 all result in a lower $\delta^{202} \mathrm{Hg}$ value for the product (e.g., HgS or goethite-Hg). However, a separate investigation of sediment contaminated by metallic $\mathrm{Hg}$ suggests that sulfide bound $\mathrm{Hg}$ displays higher $\delta^{202} \mathrm{Hg}$ values (up to $1 \%$ higher) than bulk sediment. ${ }^{86}$ These studies demonstrate that Hg fractions in sediment may have different $\delta^{202} \mathrm{Hg}$ values and future investigations of the isotopic composition of different Hg species in Yuba Fan sediment could prove valuable. However, at present we are unable to identify a specific labile $\mathrm{Hg}$ fraction, with consistently low $\delta^{202} \mathrm{Hg}$, that could explain the observed IHg-MMHg relationship. Thus, we use bulk Hg isotope measurements of sediment and algae, or the estimated IHg in the food web, to compare with MMHg in the Yuba River.

Net MDF during Biotic Processes

Previous studies have found a net positive offset in $\delta^{202} \mathrm{Hg}\left(\delta^{202} \mathrm{Hg}_{\text {pre-photodegraded }}\right.$ MMHg $\delta^{202} \mathrm{Hg}_{\mathrm{IHg}}$ ), between bulk sediment ( $\mathrm{IHg}$ ) and estimated pre-photodegraded MMHg, which ranged from +0.4 to $+0.8 \%$ in coastal oceans (San Francisco Bay, East Coast estuaries, Minamata Bay) and freshwater lakes (Michigan and Florida). ${ }^{24,25,27,62}$ Biotic methylation preferentially methylates the light isotopes of $\mathrm{Hg}$, resulting in MMHg that displays lower $\delta^{202} \mathrm{Hg}$ values than the $\mathrm{HH}$ substrate (MDF). ${ }^{87,88}$ In contrast, biotic degradation of MMHg by the mercury reductase mechanism leads to higher $\delta^{202} \mathrm{Hg}$ values for the residual MMHg (+MDF). ${ }^{89}$ Therefore, the previously observed positive offset was suggested to result from processing of $\mathrm{Hg}$ in sediment where biotic methylation is 
429 followed by significant biotic MMHg degradation, ${ }^{24,25}$ leading to a $\delta^{202} \mathrm{Hg}$ value for residual MMHg 430 that is higher than the original sediment. This residual MMHg is subsequently photodegraded 431 (+MIF and +MDF) ${ }^{56,57}$ and bioaccumulated (no MIF or MDF). ${ }^{35,54}$ In contrast, in this study the 432 estimated $\delta^{202} \mathrm{Hg}$ of pre-photodegraded MMHg in the Yuba River is significantly lower (at least $4330.4 \%$ in 2013 and at least $0.6 \%$ in 2014 ) than estimated $\delta^{202} \mathrm{Hg}$ of IHg in the food web or the 434 measured $\delta^{202} \mathrm{Hg}$ of sediment or filamentous algae. Therefore, we suggest that if MMHg is formed 435 from sediment or algae, then there is a fundamental difference in Hg biogeochemistry and resulting 436 isotope fractionation in this system. We note that all of the previous studies were in lakes, coastal 437 oceans or estuaries, whereas this is the first such study to compare IHg and estimated MMHg 438 isotopic compositions in a river system. In general, a number of environmental characteristics (e.g., DOC, redox, turbulence, 440 suspended solids, etc.) that affect MMHg formation and degradation differ between 1) rivers 441 (flowing water) and 2) lakes or marine coastal (non-flowing water) environments. These 442 characteristics might affect net MDF between IHg and MMHg by changing the extent of methylation 443 or MMHg degradation. In streams, in-situ Hg methylation in sediment, hyporheic zones, benthic 444 biofilms or filamentous algae (e.g., 13, 63, 65, 75) would be followed by MMHg advection from the 445 substrate into the water column. We would expect this transport to be greater in flowing water (i.e., 446 rivers) than in non-flowing water environments (i.e., lakes or estuaries). Turbulent diffusion of 447 MMHg has been hypothesized to increase MDF during experimental studies of net biotic 448 methylation and degradation.88 Similarly, in-situ methylation in flowing water could lead to 449 continuous removal of the MMHg product from the site of methylation and decrease the amount of 450 MMHg available for biotic degradation. This would result in less biotic degradation (less +MDF) of 451 the MMHg exported to the water column, and therefore lower $\delta^{202} \mathrm{Hg}$ values for MMHg compared to 452 the IHg substrate. Conversely, when MMHg resides for a relatively long period of time in sediment, 453 as might be the case in standing water, it could be biotically degraded to a greater extent (more 
$454+\mathrm{MDF}$ ). Significant biotic MMHg degradation would drive the residual MMHg to higher $\delta^{202} \mathrm{Hg}$

455 values than the sediment, as has been observed in lakes and coastal marine environments. Thus, the

456 extent of biotic MMHg degradation could cause the different $\delta^{202} \mathrm{Hg}$ offset between flowing and non-

457 flowing water environments. If so, our data suggests that relatively little biotic MMHg degradation

458 occurs, and photochemical degradation is a relatively more dominant degradation pathway, in the

459 Yuba River.

It is also possible that non-mer mediated biotic degradation pathways could result in

461 different MDF patterns, leading to the observed negative $\delta^{202} \mathrm{Hg}$ offset. Biotic MMHg degradation

462 can occur through either mer-mediated degradation or oxidative demethylation pathways.90,91

463 During mer-mediated degradation, MMHg is converted to $\mathrm{Hg}(0)$, which is volatile and could be

464 more easily removed from the substrate, ${ }^{91}$ resulting in residual MMHg with higher $\delta^{202} \mathrm{Hg}(+\mathrm{MDF}) .{ }^{89}$

465 Oxidative demethylation, which is considered a byproduct of microbial metabolism, likely converts

466 MMHg to Hg(II).6, 7, 92 Isotopic fractionation during oxidative demethylation has not yet been

467 measured, but during this process the Hg(II) product could undergo remethylation. We hypothesize

468 that during biotic cycling, when oxidative MMHg degradation is the dominant pathway, MMHg

469 would become enriched in light Hg isotopes through successive remethylation (-MDF) of the

470 degraded MMHg. Environmental conditions that determine preferred degradation pathways might

471 differ between flowing and non-flowing water environments. In general, oxidative demethylation is

472 expected to be dominant when bioavailable $\mathrm{Hg}$ is not at a high enough concentration to induce mer-

473 enzyme expression (i.e., low THg environments). ${ }^{90,}{ }^{92}$ However, in high THg environments,

474 geochemical conditions such as redox state, organic matter content and sulfide can control $\mathrm{Hg}$

475 bioavailability and change the dominant degradation pathway. ${ }^{90}$ Although we cannot pinpoint the 476 specific mechanism, changes in the extent or the pathway of biotic MMHg degradation are plausible

477 explanations for the observed net negative MDF between IHg and MMHg in the Yuba River. 


\section{Implications for Future Work}

This study is the first to use Hg isotopes to identify MMHg sources and infer biogeochemical 481 transformations in a stream contaminated by historical Au mining. We have characterized the 482 isotopic composition of sediment in the Yuba Fan, which may enable future tracing of sediment483 bound IHg to downstream floodplains and wetlands in the Sacramento Valley. We also estimated 484 the isotopic composition of Yuba River MMHg, which might be valuable for future studies that 485 investigate whether this MMHg is exported downstream ${ }^{79,93}$ or to the terrestrial food web.

486 Comparisons of the isotopic compositions of IHg with MMHg and pre-photodegraded MMHg 487 provided useful insight into Hg biogeochemistry in the Yuba River. The Hg isotope data suggest that 488 benthic macroinvertebrates obtain IHg from filamentous algae and sediment (i.e., through their 489 diet). Although we cannot rule out the possibility for external inputs of MMHg, we think it likely 490 that MMHg is accumulated directly from sediment and algae in the Yuba River. If this MMHg is 491 formed in situ, then the relationship between IHg (in the food web, sediment or algae) and MMHg in 492 this study is different than previous studies of lakes, estuaries and forests. We hypothesize that this 493 could be due to differences in net MDF resulting from the extent or the pathway of biotic MMHg 494 degradation in the Yuba River. If changes in biotic MMHg degradation result from characteristic 495 differences between flowing and non-flowing water environments, we would expect similar net 496 negative MDF to be observed between IHg and MMHg in other stream systems. 


\section{Acknowledgements}

500 We thank Marcus Johnson for assistance in the operation of the CV-MC-ICP-MS and Tyler Nakamura

501 and Ka'ai Jensen for their help with fieldwork. We also thank Evangelos Kakouros, Michelle Arias

502 and Le H. Kieu (USGS-Menlo Park, CA) for THg and MMHg analyses. We thank Laura Sherman for

503 reviewing a draft of this manuscript and appreciate the constructive input of three anonymous

504 reviewers. We also acknowledge financial support from the National Science Foundation: EAR-

5051225630 (to J.D.B.) and EAR-1226741 (to M.B.S.).

506

507

\section{Supporting Information}

509 Sample collection details, regional sampling map, a detailed figure legend, complementary figures

510 and three data tables. This information is available free of charge via the Internet at

511 http://pubs.acs.org/. 
Figure 1: Sediment $\delta^{202} \mathbf{H g}$ and THg vs. Distance in the Yuba and Feather Rivers. All diamonds represent sediment analyzed in this study, with grey symbols indicating THg and black symbols indicating the corresponding $\delta^{202} \mathrm{Hg}$ values $( \pm 0.08 \%$ ). Circles represent two sediment samples previously analyzed by Donovan et al. $\left({ }^{40}\right)$ from Rose Bar. Biota sampling sites are noted at the bottom of the figure at their approximate location in the river system.

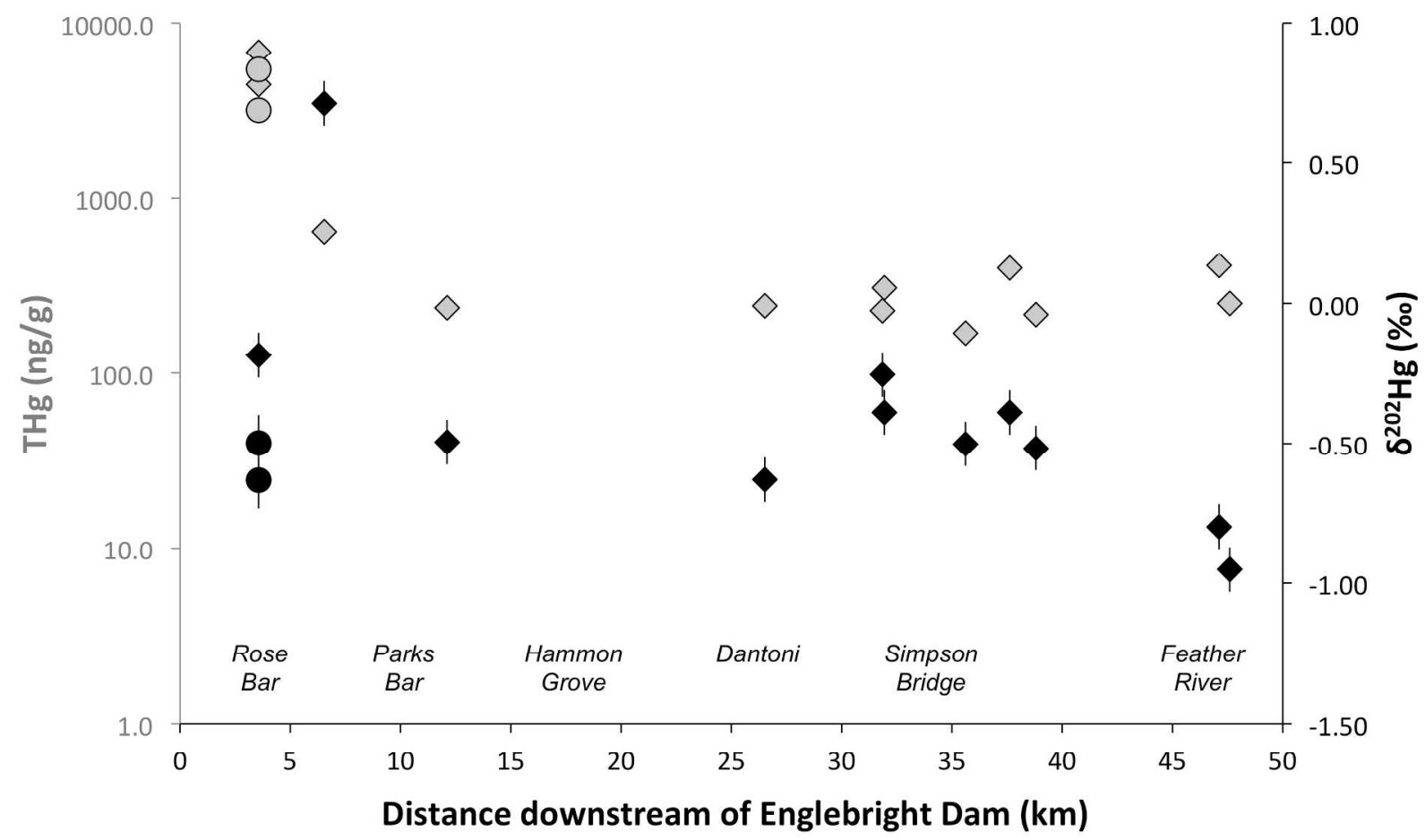


524 Figure 2: \%MMHg vs. $\Delta^{199} \mathbf{H g}$ (A, top) and $\boldsymbol{\delta}^{202} \mathbf{H g}(\mathrm{B}$, bottom) for all biota. Dark dashed lines 525 represent linear relationships for all biota samples and light grey lines (in A only) represent specific sampling years. Biota are colored corresponding to their sampling location $(\mathrm{RB}=$ red, $\mathrm{PB}=$ orange, $\mathrm{HG}=$ blue, $\mathrm{Da}=$ green, $\mathrm{SB}=$ purple, $\mathrm{FR}=$ brown). Symbols represent the sample type (stonefly = triangle, caddisfly = circle, mayfly and aq. worm = square, clam $=+$, fish $=$ asterisk and filamentous algae $=\mathrm{x}$ ). Sediment symbols are colored by stream with solid black diamonds representing Yuba

530 River sediment and solid brown diamonds representing Feather River sediment. A detailed legend 531 can be found in the Supporting Information (SI Figure 2).

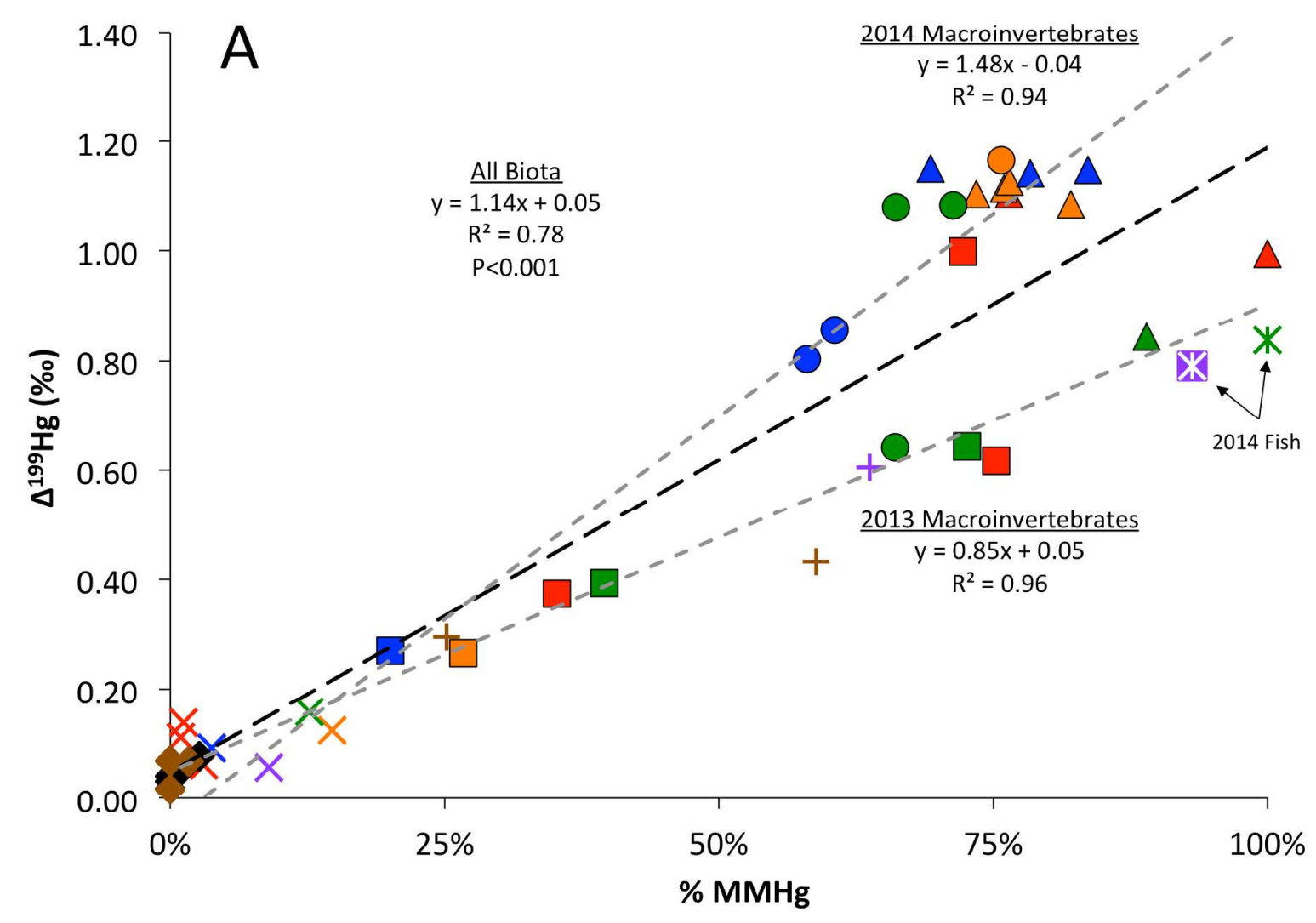




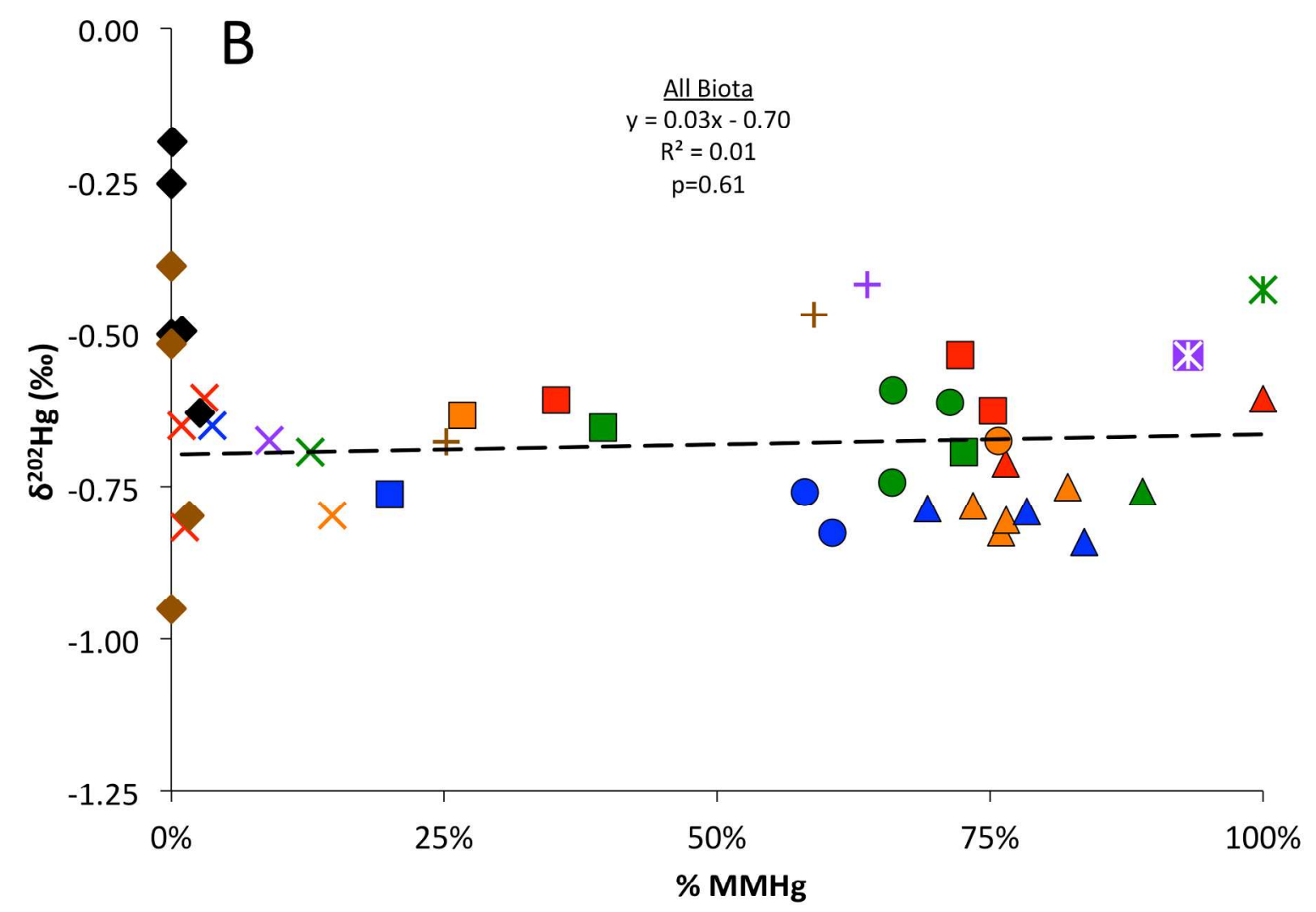

534 
Figure 3: Hg isotopic composition ( $\left(\delta^{202} \mathrm{Hg}\right.$ vs. $\Delta^{199} \mathrm{Hg}$ ) for biota and sediment in the Yuba and Feather Rivers. Symbols are identical to Figure 2 and the representative uncertainty for individual samples is indicated in the upper left hand corner $\left( \pm 0.08 \%\right.$ o for $\delta^{202} \mathrm{Hg}$ and $\pm 0.05 \%$ for $\Delta^{199} \mathrm{Hg}$ ). Estimated MMHg and IHg isotopic compositions (from linear regression) are black crosses and their size is representative of the $1 \mathrm{SE}$ uncertainty of these estimates. The $1 \mathrm{mg} / \mathrm{L} \mathrm{DOC} \mathrm{MMHg}$ photochemical degradation slope, from (56), is included as a black dashed line drawn from each

541 estimated MMHg.

542

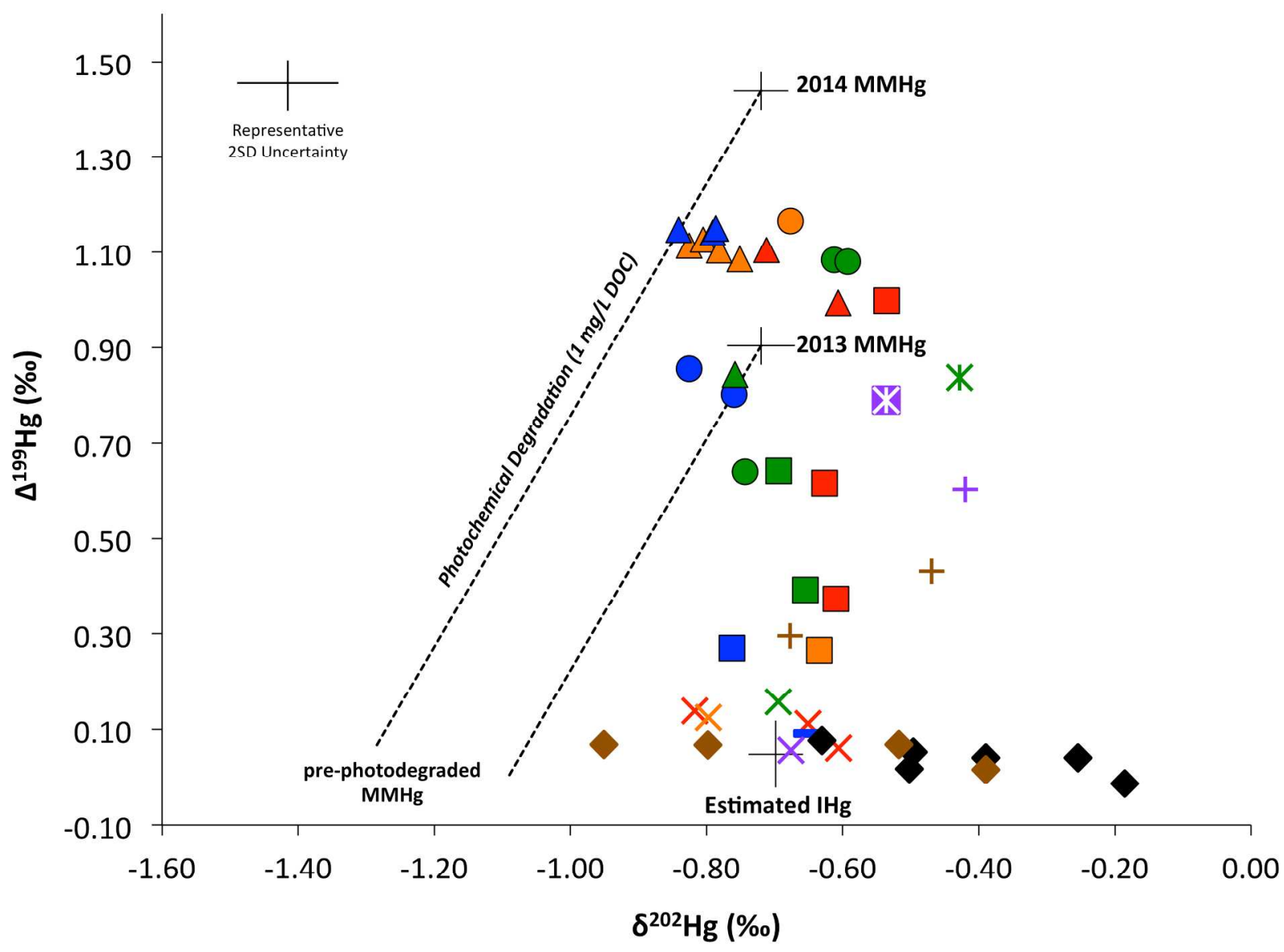


545 Figure 4: Possible explanations for the origin of MMHg in the Yuba and Feather Rivers. Either (A) methylation of sediment and algae IHg sources result in net negative biotic MDF or (B) external, watershed IHg sources $\left(\sim \delta^{202} \mathrm{Hg}\right.$ of -1 to $-2.5 \%$ ) are methylated and input to the Yuba-Feather River and net positive biotic MDF is consistent with previous studies.

549

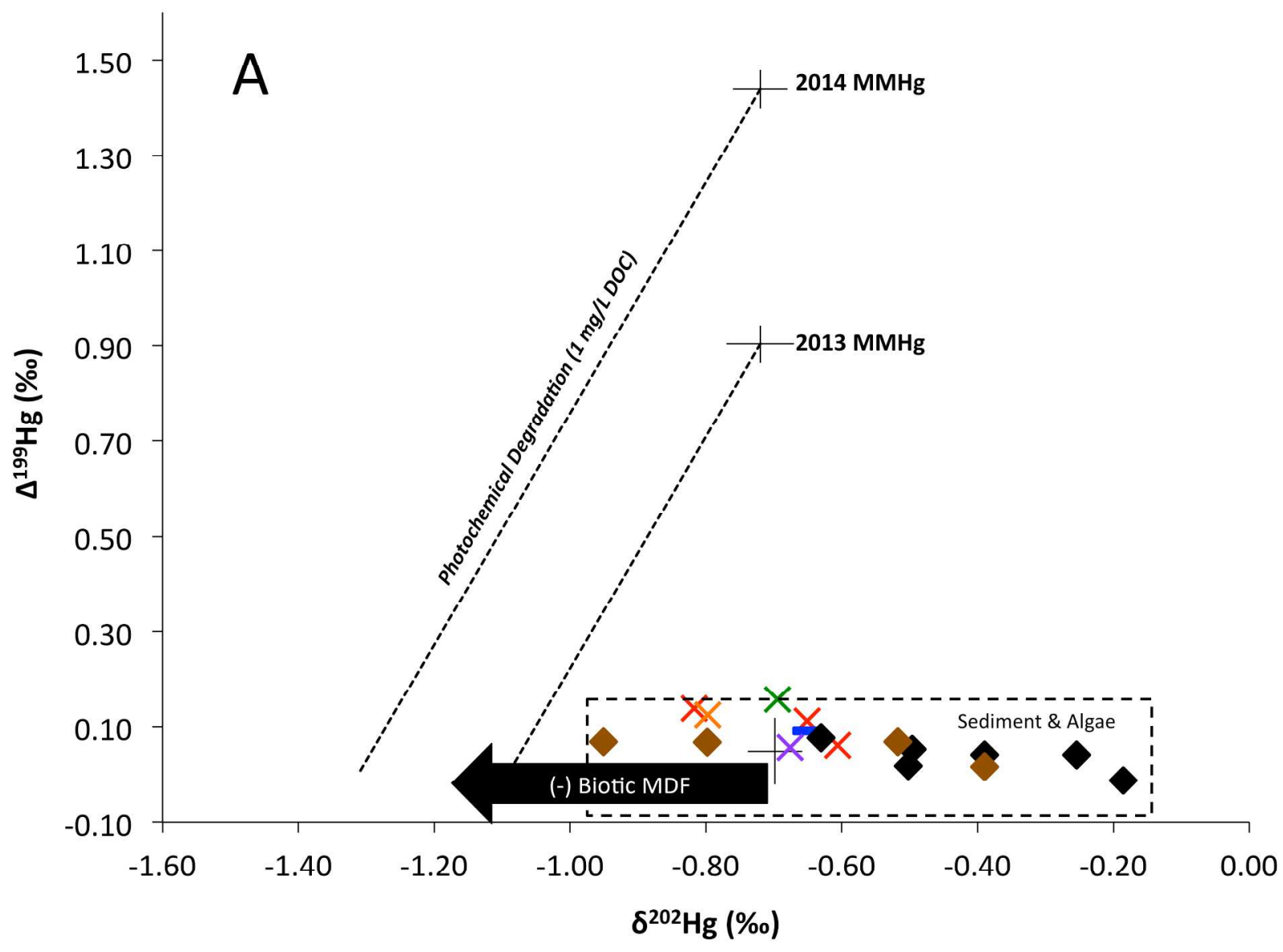




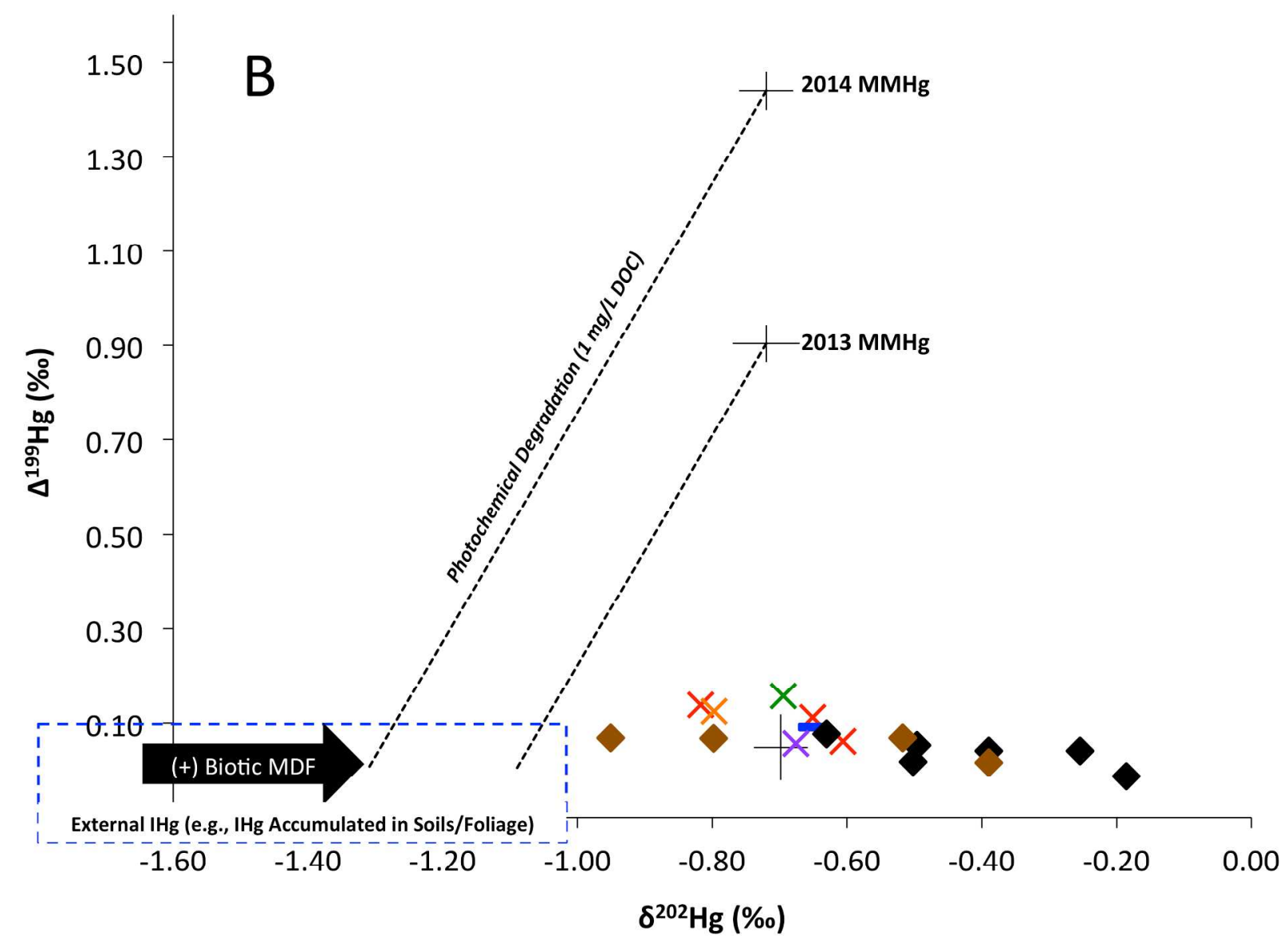


554 1. Selin, N. E., Global Biogeochemical Cycling of Mercury: A Review. Annu. Rev. Environ. Resour. 555 2009, 34, (1), 43-63.

$556 \quad 2 . \quad$ Alpers, C. N.; Hunerlach, M. P.; May, J. T.; Hothem, R. L., Mercury contamination from 557 historical gold mining in California. Fact Sheet - U. S. Geological Survey 2005, 1.

558 3. Gilbert, G. K., Hydraulic-mining debris in the Sierra Nevada. US Gov't Print. Off.: 1917.

559 4. $\quad$ Singer, M. B.; Aalto, R.; James, L. A.; Kilham, N. E.; Higson, J. L.; Ghoshal, S., Enduring legacy 560 of a toxic fan via episodic redistribution of California gold mining debris. Proceedings of the National 561 Academy of Sciences 2013, 110, (46), 18436-18441.

$562 \quad 5 . \quad$ Hunerlach, M. P.; Alpers, C. N.; Marvin-DiPasquale, M. C.; Taylor, H. E.; De Wild, J. F. 563 Geochemistry of mercury and other trace elements in fluvial tailings upstream of Daguerre Point Dam, 564 Yuba River, California, August 2001; 2004; p 77.

565 6. Ullrich, S. M.; Tanton, T. W.; Abdrashitova, S. A., Mercury in the aquatic environment: A review 566 of factors affecting methylation. Critical Reviews in Environmental Science and Technology 2001, 31, 567 (3), 241-293.

568 7. Hsu-Kim, H.; Kucharzyk, K. H.; Zhang, T.; Deshusses, M. A., Mechanisms Regulating Mercury 569 Bioavailability for Methylating Microorganisms in the Aquatic Environment: A Critical Review. Environ. 570 Sci. Technol. 2013, 47, (6), 2441-2456.

5718 8. Marvin-DiPasquale, M.; Agee, J. L., Microbial mercury cycling in sediments of the San 572 Francisco Bay-Delta. Estuaries 2003, 26, (6), 1517-1528.

$5739 . \quad$ Davis, J. A.; Looker, R. E.; Yee, D.; Marvin-Di Pasquale, M.; Grenier, J. L.; Austin, C. M.;

574 McKee, L. J.; Greenfield, B. K.; Brodberg, R.; Blum, J. D., Reducing methylmercury accumulation in the 575 food webs of San Francisco Bay and its local watersheds. Environ. Res. 2012, 119, (Special Issue), 3-26.

576 10. Marvin-DiPasquale, M. C.; Agee, J. L.; Bouse, R. M.; Jaffe, B. E., Microbial cycling of mercury 577 in contaminated pelagic and wetland sediments of San Pablo Bay, California. Environmental Geology 578 2003, 43, (3), 260-267.

579 11. Chasar, L. C.; Scudder, B. C.; Stewart, A. R.; Bell, A. H.; Aiken, G. R., Mercury Cycling in 580 Stream Ecosystems. 3. Trophic Dynamics and Methylmercury Bioaccumulation. Environ. Sci. Technol. 581 2009, 43, (8), 2733-2739.

582 12. Marvin-DiPasquale, M.; Lutz, M. A.; Brigham, M. E.; Krabbenhoft, D. P.; Aiken, G. R.; Orem, 583 W. H.; Hall, B. D., Mercury Cycling in Stream Ecosystems. 2. Benthic Methylmercury Production and 584 Bed Sediment-Pore Water Partitioning. Environ. Sci. Technol. 2009, 43, (8), 2726-2732. 
585 13. Tsui, M. T. K.; Finlay, J.; Balogh, S.; Nollet, Y., In Situ Production of Methylmercury within a Stream Channel in Northern California. Environ. Sci. Technol. 2010, 44, (18), 6998-7004.

14. Ward, D. M.; Nislow, K. H.; Folt, C. L., Bioaccumulation syndrome: identifying factors that make some stream food webs prone to elevated mercury bioaccumulation. Ann. N. Y. Acad. Sci. 2010, $1195,(1), 62-83$.

$590 \quad$ 15. Walters, D. M.; Raikow, D. F.; Hammerschmidt, C. R.; Mehling, M. G.; Kovach, A.; Oris, J. T., 591 Methylmercury Bioaccumulation in Stream Food Webs Declines with Increasing Primary Production.

592 Environ. Sci. Technol. 2015, 49, (13), 7762-7769.

$593 \quad$ 16. Fleck, J. A.; Alpers, C. N.; Marvin-DiPasquale, M.; Hothem, R. L.; Wright, S. A.; Ellett, K.; Beaulieu, E.; Agee, J. L.; Kakouros, E.; Kieu, L. H.; Eberl, D. D.; Blum, A. E.; May, J. T., The effects of sediment and mercury mobilization in the south Yuba River and Humbug Creek confluence area, Nevada County, California; concentrations, speciation, and environmental fate; Part 1, Field characterization. Open-File Report - U. S. Geological Survey 2011, 1.

17. Marvin-DiPasquale, M.; Agee, J. L.; Kakouros, E.; Kieu, L. H.; Fleck, J. A.; Alpers, C. N., The effects of sediment and mercury mobilization in the South Yuba River and Humbug Creek confluence area, Nevada County, California; concentrations, speciation, and environmental fate; Part 2, Laboratory experiments. Open-File Report - U. S. Geological Survey 2011, 1. region affected by historic gold mining: the South Yuba River, Deer Creek, and Bear River watersheds, California, 1999. 2000. waters and sediments of the Murray Brook mine watershed (New Brunswick, Canada): Tracing mercury contamination and transformation. Chem. Geol. 2013, 336, (0), 87-95.

608 20. Foucher, D.; Ogrinc, N.; Hintelmann, H., Tracing Mercury Contamination from the Idrija Mining 609 Region (Slovenia) to the Gulf of Trieste Using Hg Isotope Ratio Measurements. Environ. Sci. Technol. 610 2009, 43, (1), 33-39.

611 21. Donovan, P. M.; Blum, J. D.; Demers, J. D.; Gu, B.; Brooks, S. C.; Peryam, J., Identification of 612 Multiple Mercury Sources to Stream Sediments near Oak Ridge, TN, USA. Environ. Sci. Technol. 2014, 613 48, (7), 3666-3674.

614 22. Gray, J. E.; Van Metre, P. C.; Pribil, M. J.; Horowitz, A. J., Tracing historical trends of Hg in the 615 Mississippi River using $\mathrm{Hg}$ concentrations and $\mathrm{Hg}$ isotopic compositions in a lake sediment core, Lake 616 Whittington, Mississippi, USA. Chem. Geol. 2015, 395, (0), 80-87.

617 23. Smith, R. S.; Wiederhold, J. G.; Jew, A. D.; Brown, G. E.; Bourdon, B.; Kretzschmar, R., Stable $618 \mathrm{Hg}$ Isotope Signatures in Creek Sediments Impacted by a Former Hg Mine. Environ. Sci. Technol. 2015, $61949,(2), 767-776$. 
620 24. Sherman, L. S.; Blum, J. D., Mercury stable isotopes in sediments and largemouth bass from 621 Florida lakes, USA. Sci. Total Environ. 2013, 448, (0), 163-175.

622 25. Gehrke, G. E.; Blum, J. D.; Slotton, D. G.; Greenfield, B. K., Mercury Isotopes Link Mercury in 623 San Francisco Bay Forage Fish to Surface Sediments. Environ. Sci. Technol. 2011, 45, (4), 1264-1270.

624 26. Kwon, S. Y.; Blum, J. D.; Nadelhoffer, K. J.; Timothy Dvonch, J.; Tsui, M. T.-K., Isotopic study 625 of mercury sources and transfer between a freshwater lake and adjacent forest food web. Sci. Total 626 Environ. 2015, 532, (0), 220-229.

627 27. Kwon, S. Y.; Blum, J. D.; Chen, C. Y.; Meattey, D. E.; Mason, R. P., Mercury Isotope Study of 628 Sources and Exposure Pathways of Methylmercury in Estuarine Food Webs in the Northeastern US.

629 Environ. Sci. Technol. 2014, 48, (17), 10089-10097.

630 28. Tsui, M. T. K.; Blum, J. D.; Kwon, S. Y.; Finlay, J. C.; Balogh, S. J.; Nollet, Y. H., Sources and 631 Transfers of Methylmercury in Adjacent River and Forest Food Webs. Environ. Sci. Technol. 2012, 46, 632 (20), 10957-10964.

633 29. Tsui, M. T. K.; Blum, J. D.; Finlay, J. C.; Balogh, S. J.; Nollet, Y. H.; Palen, W. J.; Power, M. E., 634 Variation in Terrestrial and Aquatic Sources of Methylmercury in Stream Predators as Revealed by Stable 635 Mercury Isotopes. Environ. Sci. Technol. 2014, 48, (17), 10128-10135.

636 30. Tsui, M. T. K.; Blum, J. D.; Finlay, J. C.; Balogh, S. J.; Kwon, S. Y.; Nollet, Y. H., 637 Photodegradation of methylmercury in stream ecosystems. Limnol. Oceanogr 2013, 58, (1), 13-22.

638 31. Hammerschmidt, C.; Fitzgerald, W., Bioaccumulation and Trophic Transfer of Methylmercury in 639 Long Island Sound. Arch. Environ. Contam. Toxicol. 2006, 51, (3), 416-424.

$640 \quad 32 . \quad$ USEPA Method 1630: Methyl Mercury in Water by Distillation, Aqueous Ethylation, Purge and 641 Trap, and CVAFS; U.S. Environmental Protection Agency, Office of Water, Office of Science and 642 Technology, Engineering and Analysis Division: Washington, D.C., 2001.

643 33. Demers, J. D.; Blum, J. D.; Zak, D. R., Mercury isotopes in a forested ecosystem: Implications 644 for air-surface exchange dynamics and the global mercury cycle. Global Biogeochem. Cycles 2013, 27, 645 (1), 222-238.

646 34. Blum, J. D.; Bergquist, B. A., Reporting of variations in the natural isotopic composition of 647 mercury. Anal. Bioanal. Chem. 2007, 388, (2), 353-359.

$648 \quad 35 . \quad$ Kwon, S. Y.; Blum, J. D.; Chirby, M. A.; Chesney, E. J., Application of mercury isotopes for 649 tracing trophic transfer and internal distribution of mercury in marine fish feeding experiments. Environ.

650 Toxicol. Chem. 2013, 32, (10), 2322-2330.

651 36. Masbou, J.; Point, D.; Sonke, J. E., Application of a selective extraction method for 652 methylmercury compound specific stable isotope analysis (MeHg-CSIA) in biological materials. J. Anal. 653 At. Spectrom. 2013, 28, (10), 1620-1628. 
654 37. Cooke, C. A.; Hintelmann, H.; Ague, J. J.; Burger, R.; Biester, H.; Sachs, J. P.; Engstrom, D. R., 655 Use and Legacy of Mercury in the Andes. Environ. Sci. Technol. 2013, 47, (9), 4181-4188.

656 38. Biswas, A.; Blum, J. D.; Bergquist, B. A.; Keeler, G. J.; Xie, Z. Q., Natural Mercury Isotope 657 Variation in Coal Deposits and Organic Soils. Environ. Sci. Technol. 2008, 42, (22), 8303-8309.

658 39. Sonke, J. E.; Schafer, J.; Chmeleff, J.; Audry, S.; Blanc, G.; DuprÈ, B., Sedimentary mercury 659 stable isotope records of atmospheric and riverine pollution from two major European heavy metal 660 refineries. Chem. Geol. 2010, 279, (3-4), 90-100.

661 40. Donovan, P. M.; Blum, J. D.; Yee, D.; Gehrke, G. E.; Singer, M. B., An isotopic record of 662 mercury in San Francisco Bay sediment. Chem. Geol. 2013, 349-350, (0), 87-98.

663 41. Laffont, L.; Sonke, J. E.; Maurice, L.; Monrroy, S. L.; Chincheros, J.; Amouroux, D.; Behra, P., $664 \mathrm{Hg}$ Speciation and Stable Isotope Signatures in Human Hair As a Tracer for Dietary and Occupational 665 Exposure to Mercury. Environ. Sci. Technol. 2011, 45, (23), 9910-9916.

666 42. Yin, R.; Feng, X.; Wang, J.; Li, P.; Liu, J.; Zhang, Y.; Chen, J.; Zheng, L.; Hu, T., Mercury 667 speciation and mercury isotope fractionation during ore roasting process and their implication to source 668 identification of downstream sediment in the Wanshan mercury mining area, SW China. Chem. Geol. $6692013,336,(0), 72-79$.

670 43. Smith, C. N.; Kesler, S. E.; Blum, J. D.; Rytuba, J. J., Isotope geochemistry of mercury in source 671 rocks, mineral deposits and spring deposits of the California Coast Ranges, USA. Earth Planet. Sci. Lett. 672 2008, 269, (3-4), 398-406.

673 44. William Miller, J.; Callahan, J. E.; Craig, J. R., Mercury interactions in a simulated gold placer. 674 Appl. Geochem. 2002, 17, (1), 21-28.

675 45. Slowey, A. J.; Rytuba, J. J.; Brown, G. E., Speciation of Mercury and Mode of Transport from 676 Placer Gold Mine Tailings. Environ. Sci. Technol. 2005, 39, (6), 1547-1554.

677 46. Bartov, G.; Deonarine, A.; Johnson, T. M.; Ruhl, L.; Vengosh, A.; Hsu-Kim, H., Environmental 678 Impacts of the Tennessee Valley Authority Kingston Coal Ash Spill. 1. Source Apportionment Using 679 Mercury Stable Isotopes. Environ. Sci. Technol. 2012, 47, (4), 2092-2099.

680 47. Kilham, N. E.; Roberts, D.; Singer, M. B., Remote sensing of suspended sediment concentration 681 during turbid flood conditions on the Feather River, California - a modeling approach. Water Resour. Res. 682 2012, 48, (1).

683 48. Higson, J. L.; Singer, M. B., The impact of the streamflow hydrograph on sediment supply from 684 terrace erosion. Geomorphology 2015, 248, 475-488.

685 49. Slotton, D. G.; Ayers, S. M.; Reuter, J. E.; Goldman, C. R., Gold Mining Impacts on Food Chain 686 Mercury in Northwestern Sierra Nevada Streams. In University of California Water Resources Center: 6871995. 
50. Alpers, C. N.; Hunerlach, M. P.; May, J. T.; Hothem, R. L.; Taylor, H. E.; Antweiler, R. C.; De Wild, J. F.; Lawler, D. A., Geochemical characterization of water, sediment, and biota affected by mercury contamination and acidic drainage from historical gold mining, Greenhorn Creek, Nevada County, California, 1999-2001. 2004.

51. Tsui, M. T. K.; Finlay, J. C.; Nater, E. A., Mercury Bioaccumulation in a Stream Network. Environ. Sci. Technol. 2009, 43, (18), 7016-7022.

52. Slotton, D. G.; Ayers, S. M.; Suchanek, T. H.; Weyand, R. D.; Liston, A. M., Mercury bioaccumulation and trophic transfer in the Cache Creek watershed of California, in relation to diverse aqueous mercury exposure conditions. Report to the California Bay Delta Authority, Sacramento 2004.

53. Mathews, T. J.; Smith, J. G.; Peterson, M. J.; Roy, W. K., Assessment of Contaminant Bioaccumulation in Invertebrates and Fish in Waters On and Adjacent to the Oak Ridge Reservation 2010. ORNL-TM (Oak Ridge National Laboratory) 2011, 2011/108.

54. Kwon, S. Y.; Blum, J. D.; Carvan, M. J.; Basu, N.; Head, J. A.; Madenjian, C. P.; David, S. R., Absence of Fractionation of Mercury Isotopes during Trophic Transfer of Methylmercury to Freshwater Fish in Captivity. Environ. Sci. Technol. 2012, 46, (14), 7527-7534.

55. Rose, C. H.; Ghosh, S.; Blum, J. D.; Bergquist, B. A., Effects of ultraviolet radiation on mercury isotope fractionation during photo-reduction for inorganic and organic mercury species. Chem. Geol. 2015, 405, 102-111.

56. Bergquist, B. A.; Blum, J. D., Mass-dependent and -independent fractionation of $\mathrm{Hg}$ isotopes by photoreduction in aquatic systems. Science 2007, 318, (5849), 417-420.

57. Chandan, P.; Ghosh, S.; Bergquist, B. A., Mercury Isotope Fractionation during Aqueous Photoreduction of Monomethylmercury in the Presence of Dissolved Organic Matter. Environ. Sci. Technol. 2015, 49, (1), 259-267.

58. Blum, J. D.; Sherman, L. S.; Johnson, M. W., Mercury Isotopes in Earth and Environmental Sciences. Annu. Rev. Earth Planet. Sci. 2014, 42, (1), 249-269.

59. Zheng, W.; Hintelmann, H., Mercury isotope fractionation during photoreduction in natural water is controlled by its Hg/DOC ratio. Geochim. Cosmochim. Acta 2009, 73, (22), 6704-6715.

60. Chow, A. T.; Dahlgren, R. A.; Harrison, J. A., Watershed sources of disinfection byproduct precursors in the Sacramento and San Joaquin Rivers, California. Environ. Sci. Technol. 2007, 41, (22), $7645-7652$.

61. Blum, J. D.; Popp, B. N.; Drazen, J. C.; Choy, C. A.; Johnson, M. W., Methylmercury production below the mixed layer in the North Pacific Ocean. Nature Geoscience 2013, 6, (10), 879-884. 
720 62. Balogh, S. J.; Tsui, M. T. K.; Blum, J. D.; Matsuyama, A.; Woerndle, G. E.; Yano, S.; Tada, A., 721 Tracking the Fate of Mercury in the Fish and Bottom Sediments of Minamata Bay, Japan, Using Stable 722 Mercury Isotopes. Environ. Sci. Technol. 2015, 49, (9), 5399-5406.

723 63. Hamelin, S. p.; Planas, D.; Amyot, M., Mercury methylation and demethylation by periphyton 724 biofilms and their host in a fluvial wetland of the St. Lawrence River (QC, Canada). Sci. Total Environ. 725 2015, 512, 464-471.

726 64. Bell, A. H.; Scudder, B. C., Mercury Accumulation in Periphyton of Eight River Ecosystems. 727 JAWRA Journal of the American Water Resources Association 2007, 43, (4), 957-968.

728 65. Buckman, K. L.; Marvin-Di Pasquale, M.; Taylor, V. F.; Chalmers, A.; Broadley, H. J.; Agee, J.; 729 Jackson, B. P.; Chen, C. Y., Influence of a chlor-alkali superfund site on mercury bioaccumulation in 730 periphyton and low-trophic level fauna. Environ. Toxicol. Chem. 2015, 34, (7), 1649-1658.

731 66. Balogh, S. J.; Nollet, Y. H.; Offerman, H. J., A comparison of total mercury and methylmercury 732 export from various Minnesota watersheds. Sci. Total Environ. 2005, 340, (1), 261-270.

733 67. Harris, R. C.; Rudd, J. W.; Amyot, M.; Babiarz, C. L.; Beaty, K. G.; Blanchfield, P. J.; Bodaly, 734 R.; Branfireun, B. A.; Gilmour, C. C.; Graydon, J. A., Whole-ecosystem study shows rapid fish-mercury 735 response to changes in mercury deposition. Proceedings of the National Academy of Sciences 2007, 104, 736 (42), 16586-16591.

737 68. Gratz, L. E.; Keeler, G. J.; Blum, J. D.; Sherman, L. S., Isotopic Composition and Fractionation 738 of Mercury in Great Lakes Precipitation and Ambient Air. Environ. Sci. Technol. 2010, 44, (20), 77647397770 .

$740 \quad$ 69. Sherman, L. S.; Blum, J. D.; Keeler, G. J.; Demers, J. D.; Dvonch, J. T., Investigation of Local 741 Mercury Deposition from a Coal-Fired Power Plant Using Mercury Isotopes. Environ. Sci. Technol. 2011, $742 \quad 46,(1), 382-390$.

743 70. Chen, J.; Hintelmann, H.; Feng, X.; Dimock, B., Unusual fractionation of both odd and even 744 mercury isotopes in precipitation from Peterborough, ON, Canada. Geochim. Cosmochim. Acta 2012, 90, $745(0), 33-46$.

746 71. Demers, J. D.; Driscoll, C. T.; Fahey, T. J.; Yavitt, J. B., Mercury Cycling in Litter and Soil in 747 Different Forest Types in the Adirondack Region, New York, USA. Ecological Applications 2007, 17, $748 \quad$ (5), 1341-1351.

749 72. Balogh, S. J.; Meyer, M. L.; Johnson, D. K., Transport of Mercury in Three Contrasting River 750 Basins. Environ. Sci. Technol. 1998, 32, (4), 456-462.

751 73. Gray, J. E.; Hines, M. E., Biogeochemical mercury methylation influenced by reservoir 752 eutrophication, Salmon Falls Creek Reservoir, Idaho, USA. Chem. Geol. 2009, 258, (3), 157-167. 
753 74. Schetagne, R.; Doyon, J.-F.; Fournier, J.-J., Export of mercury downstream from reservoirs. Sci. 754 Total Environ. 2000, 260, (1), 135-145.

755 75. Stoor, R. W.; Hurley, J. P.; Babiarz, C. L.; Armstrong, D. E., Subsurface sources of methyl 756 mercury to Lake Superior from a wetland, Äiforested watershed. Sci. Total Environ. 2006, 368, (1), 99757110.

758 76. Hinkle, S.; Bencala, K.; Wentz, D.; Krabbenhoft, D., Mercury and Methylmercury Dynamics in 759 the Hyporheic Zone of an Oregon Stream. Water Air Soil Pollut 2013, 225, (1), 1-17.

760 77. Hall, G. E. M.; Pelchat, P., The design and application of sequential extractions for mercury, Part 761 2. Resorption of mercury onto the sample during leaching. Geochemistry: Exploration, Environment, 762 Analysis 2005, 5, (2), 115-121.

763 78. Bloom, N. S.; Preus, E.; Katon, J.; Hiltner, M., Selective extractions to assess the 764 biogeochemically relevant fractionation of inorganic mercury in sediments and soils. Anal. Chim. Acta 765 2003, 479, (2), 233-248.

766 79. Marvin-DiPasquale, M.; Windham-Myers, L.; Agee, J. L.; Kakouros, E.; Kieu, L. H.; Fleck, J. 767 A.; Alpers, C. N.; Stricker, C. A., Methylmercury production in sediment from agricultural and non768 agricultural wetlands in the Yolo Bypass, California, USA. Sci. Total Environ. 2014, 484, (0), 288-299.

769 80. Wiederhold, J. G.; Smith, R. S.; Siebner, H.; Jew, A. D.; Brown, G. E.; Bourdon, B.;

770 Kretzschmar, R., Mercury Isotope Signatures as Tracers for Hg Cycling at the New Idria Hg Mine.

771 Environ. Sci. Technol. 2013, 47, (12), 6137-6145.

772 81. Stetson, S. J.; Gray, J. E.; Wanty, R. B.; Macalady, D. L., Isotopic Variability of Mercury in Ore, 773 Mine-Waste Calcine, and Leachates of Mine-Waste Calcine from Areas Mined for Mercury. Environ. Sci. 774 Technol. 2009, 43, (19), 7331-7336.

775 82. Yin, R.; Feng, X.; Wang, J.; Bao, Z.; Yu, B.; Chen, J., Mercury isotope variations between 776 bioavailable mercury fractions and total mercury in mercury contaminated soil in Wanshan Mercury 777 Mine, SW China. Chem. Geol. 2012, 336, (Special Issue), 80-86.

778 83. Smith, R. S.; Wiederhold, J. G.; Kretzschmar, R., Mercury isotope fractionation during 779 precipitation of metacinnabar (HgS) and montroydite (HgO). Environ. Sci. Technol. 2015, 49, (7), 43257804334.

$781 \quad 84 . \quad$ Jiskra, M.; Wiederhold, J. G.; Bourdon, B.; Kretzschmar, R., Solution Speciation Controls 782 Mercury Isotope Fractionation of $\mathrm{Hg}(\mathrm{II})$ Sorption to Goethite. Environ. Sci. Technol. 2012, 46, (12), $783 \quad 6654-6662$.

$784 \quad$ 85. Wiederhold, J. G.; Cramer, C. J.; Daniel, K.; Infante, I.; Bourdon, B.; Kretzschmar, R., 785 Equilibrium Mercury Isotope Fractionation between Dissolved Hg(II) Species and Thiol-Bound Hg. 786 Environ. Sci. Technol. 2010, 44, (11), 4191-4197. 
$787 \quad$ 86. Wiederhold, J. G.; Skyllberg, U.; Drott, A.; Jiskra, M.; Jonsson, S.; Bjorn, E.; Bourdon, B.; 788 Kretzschmar, R., Mercury Isotope Signatures in Contaminated Sediments as a Tracer for Local Industrial 789 Pollution Sources. Environ. Sci. Technol. 2015, 49, (1), 177-185.

790 87. Rodriguez-Gonzalez, P.; Epov, V. N.; Bridou, R.; Tessier, E.; Guyoneaud, R.; Monperrus, M.;

791 Amouroux, D., Species-Specific Stable Isotope Fractionation of Mercury during Hg(II) Methylation by an 792 Anaerobic Bacteria (Desulfobulbus propionicus) under Dark Conditions. Environ. Sci. Technol. 2009, 43, 793 (24), 9183-9188.

794 88. Perrot, V.; Bridou, R.; Pedrero, Z.; Guyoneaud, R.; Monperrus, M.; Amouroux, D., Identical Hg 795 Isotope Mass Dependent Fractionation Signature during Methylation by Sulfate-Reducing Bacteria in 796 Sulfate and Sulfate-Free Environment. Environ. Sci. Technol. 2015, 49, (3), 1365-1373.

797 89. Kritee, K.; Barkay, T.; Blum, J. D., Mass dependent stable isotope fractionation of mercury 798 during mer mediated microbial degradation of monomethylmercury. Geochim. Cosmochim. Acta 2009, $79973,(5), 1285-1296$.

800 90. Marvin-DiPasquale, M.; Agee, J.; McGowan, C.; Oremland, R. S.; Thomas, M.; Krabbenhoft, D.; 801 Gilmour, C. C., Methyl-mercury degradation pathways: A comparison among three mercury-impacted 802 ecosystems. Environ. Sci. Technol. 2000, 34, (23), 4908-4916.

803 91. Benoit, J.; Gilmour, C.; Heyes, A.; Mason, R.; Miller, C., Geochemical and biological controls 804 over methylmercury production and degradation in aquatic ecosystems (Biogeochemistry of

805 Environmentally Important Trace Elements). ACS Symp. Ser. 2003, 835, 262-297.

806 92. Schaefer, J. K.; Yagi, J.; Reinfelder, J. R.; Cardona, T.; Ellickson, K. M.; Tel-Or, S.; Barkay, T., 807 Role of the bacterial organomercury lyase (MerB) in controlling methylmercury accumulation in 808 mercury-contaminated natural waters. Environ. Sci. Technol. 2004, 38, (16), 4304-4311.

809 93. Springborn, M.; Singer, M. B.; Dunne, T., Sediment-adsorbed total mercury flux through Yolo 810 Bypass, the primary floodway and wetland in the Sacramento Valley, California. Sci. Total Environ. 811 2011, 412, (0), 203-213. 